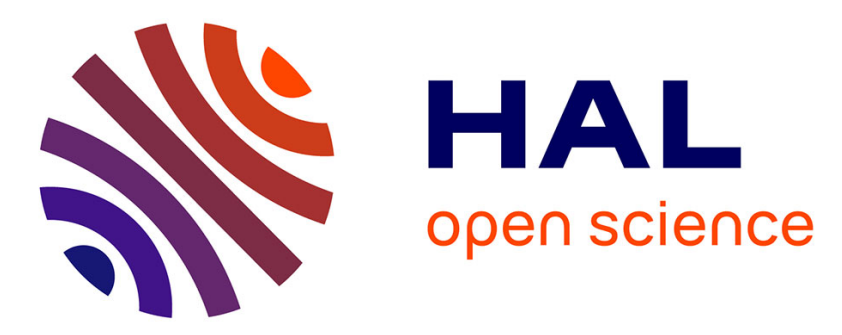

\title{
Disubstituted Ferrocenyl Iodo- and Chalcogenoalkynes as Chiral Halogen and Chalcogen Bond Donors
}

\author{
Victor Mamane, Paola Peluso, Emmanuel Aubert, Robin Weiss, Emmanuel
}

Wenger, Sergio Cossu, Patrick Pale

\section{To cite this version:}

Victor Mamane, Paola Peluso, Emmanuel Aubert, Robin Weiss, Emmanuel Wenger, et al.. Disubstituted Ferrocenyl Iodo- and Chalcogenoalkynes as Chiral Halogen and Chalcogen Bond Donors. Organometallics, 2020, 10.1021/acs.organomet.0c00633 . hal-02983655

\section{HAL Id: hal-02983655 \\ https://hal.science/hal-02983655}

Submitted on 30 Oct 2020

HAL is a multi-disciplinary open access archive for the deposit and dissemination of scientific research documents, whether they are published or not. The documents may come from teaching and research institutions in France or abroad, or from public or private research centers.
L'archive ouverte pluridisciplinaire HAL, est destinée au dépôt et à la diffusion de documents scientifiques de niveau recherche, publiés ou non, émanant des établissements d'enseignement et de recherche français ou étrangers, des laboratoires publics ou privés. 


\title{
Disubstituted Ferrocenyl Iodo- and Chalcogeno-Alkynes as Chiral Halogen and Chalcogen Bond Donors
}

\author{
Victor Mamane ${ }^{*, \dagger}$, Paola Peluso ${ }^{*,}$, Emmanuel Aubert, $₫$ Robin Weiss, ${ }^{\dagger}$ Emmanuel Wenger,, Sergio \\ Cossu," and Patrick Pale ${ }^{\dagger}$ \\ ${ }^{\dagger}$ Institut de Chimie de Strasbourg, UMR CNRS 7177, Equipe LASYROC, 1 rue Blaise Pascal, 67008 Strasbourg Cedex, \\ France. \\ * Istituto di Chimica Biomolecolare ICB, CNR, Sede secondaria di Sassari, Traversa La Crucca 3, Regione Baldinca, \\ 07100 Li Punti, Sassari, Italy. \\ § Cristallographie, Résonance Magnétique et Modélisations (CRM2), UMR CNRS 7036, Université de Lorraine, Bd des \\ Aiguillettes, 54506 Vandoeuvre-les-Nancy, France. \\ 'Dipartimento di Scienze Molecolari e Nanosistemi DSMN, Università Ca' Foscari Venezia, Via Torino 155, 30172 \\ Mestre Venezia, Italy.
}

Supporting Information Placeholder

\begin{abstract}
Asymmetric catalysis based on halogen and chalcogen bonds (XB and $\mathrm{ChB}$ ) is in its infancy and the search for new chiral $\mathrm{XB}$ and $\mathrm{ChB}$ donors represents a crucial step towards its development. In this context, we designed and prepared new motifs containing three key substructures, namely regions of electron charge density depletion centred on iodine and chalcogen atoms, the ethynyl functionality and the planar chiral ferrocenyl platform. Nine ferrocenyl iodoalkynes were prepared as pure enantiomers by asymmetric synthesis. The XB donor property of racemic ferrocenyl iodoalkynes was demonstrated in solution in two benchmark reactions: the Ritter reaction and the benzoxazole synthesis from thioamides. In contrast, the ferrocenyl chalcogenoalkynes were far less active in these reactions. The potential of racemic and enantiopure ferrocenyl iodoalkynes as XB donors were also confirmed by X-ray diffraction analysis observing I $\cdots \mathrm{C}$ contacts between the electropositive $\sigma$-hole of the iodine atom and electron rich $\pi$ clouds for all crystal structures studied in the solid state.
\end{abstract}

\section{INTRODUCTION}

In the last few years, halogen and chalcogen bonds (XB and $\mathrm{ChB}$, respectively) have been recognized as important noncovalent interactions and rationalized through the socalled $\sigma$-hole which characterizes a covalently-bonded atom of Groups 13-18. ${ }^{1}$ These atoms ( $\sigma$-hole donors) bear a region with a positive electrostatic potential on unpopulated $\sigma^{*}$ orbitals allowing them to interact with a negative site ( $\sigma$-hole acceptor: anion, lone electron pair, $\pi$ electrons).

Applications based on $\mathrm{XB}$ and $\mathrm{ChB}$ have rapidly grown during the last 20 years and important developments emerged in crystal engineering, in biology, in supramolecular chemistry and in catalysis. ${ }^{2-8}$ However, the involvement of $\mathrm{XB}$ and $\mathrm{ChB}$ in stereoselective processes remained unexplored until recently. We described XB- and ChB-driven HPLC enantioseparations of polyhalogenated 4,4'-bipyridines and related recognition mechanisms. . $^{9-14}$ Beer's group described the enantioselective recognition of chiral anions of BINOL-based XB donors ${ }^{15-18}$ and Kanger's group developed chiral triazole-based XB donors for the enantiodiscrimination of neutral acceptors. ${ }^{19,20}$ In the field of catalysis, it is worth mentioning the works of Arai and co-workers who obtained good enantiomeric excesses in asymmetric Mannich reactions between malononitrile and $N$-Boc imines or $N$-Boc $\alpha$-ketiminoesters using a quinidinebased chiral catalyst bearing a neutral XB donor functionality. ${ }^{21,22}$ More recently, Huber and co-workers described the first example of asymmetric catalysis using a pure $\mathrm{XB}$ donor catalyst. ${ }^{23}$ Despite these achievements, XB and ChB driven stereoselective processes and in particular asymmetric catalysis still remain huge challenges, as is the design of appropriate $\mathrm{XB}$ or $\mathrm{ChB}$ chiral donor molecules. ${ }^{24}$

In general, electron-withdrawing residues increase the $\sigma$ holes of $\mathrm{X}$ and $\mathrm{Ch}$ atoms. In this regard, perfluorinated and cationic $N$-heterocyclic molecules are widely used for the synthesis of strong $\mathrm{XB}$ and $\mathrm{ChB}$ donors which found various applications to organocatalysis. ${ }^{7,8}$ A different approach to increase $\sigma$-hole is to attach the halogen atom, in particular iodine, to an acetylenic unit. Indeed, in these compounds, iodine is directly attached to a $C_{s p}$ where contribution of the s orbital is higher compared to $\mathrm{sp}^{2}$ and $\mathrm{sp}^{3}$ carbons. Remarkably, iodoalkynes are good building blocks in crystal engineering $25-27$ but they are far less described in solution as XB donor. However, it is known for a long time that iodoalkynes can form strong XB adducts in solution with Lewis bases, such adducts being observed by UV-vis ${ }^{28}$ 
and by NMR. ${ }^{29}$ Two recent examples highlighted the potential of these compounds in organic synthesis, the iodoalkyne behaving either as catalyst ${ }^{30}$ or as activator. ${ }^{31}$ The analogs thio- and selenoalkynes are known as stable useful synthons in organic synthesis, ${ }^{32-35}$ but the $\sigma$-hole donor properties of sulfur and selenium in these derivatives have never been considered. It is thus worth exploring and possibly exploiting iodo- and more specifically thio- and selenoalkynes as XB or ChB (chiral) donors.

With the aim to develop new chiral XB and ChB donor molecules, we report herein the synthesis of chiral ferrocenyl iodo- and chalcogeno-alkynes by combining the $\sigma$-hole donor properties of iodine, sulfur and selenium when bonded to an alkyne, and the planar chirality of ferrocene. ${ }^{36}$ As the ferrocene substitution pattern might influence iodine polarizability, both 1,2- and 1,3disubstituted chiral ferrocene derivatives were considered in this work. Compared to 1,2-disubstituted ferrocenes whose applications are numerous, ${ }^{37,38}$ the 1,3disubstituted ferrocenes are much less described in the literature. A few derivatives have been reported with interesting activity in catalysis, ${ }^{39}$ medicinal chemistry ${ }^{40}$ and supramolecular chemistry, serving as hydrogen-bond ${ }^{41}$ or $\mathrm{XB}^{42}$ receptors.

The $\sigma$-hole donor property of the selected compounds was investigated in solution by preliminary evaluation of their performance in the Ritter reaction $^{43}$ and in the benzoxazole synthesis from thioamides. ${ }^{30}$ The potential of racemic and enantiopure ferrocenyl iodoalkynes as XB donors was also evaluated in the solid state by X-ray diffraction (XRD) analysis.

\section{RESULTS AND DISCUSSION}

Design and electrostatic potential analysis. The design of the compounds reported here was based on 1,2- or 1,3disubstituted ferrocenes, in which one of the substituents is the iodo-, thio- and selenoethynyl moiety carrying $\sigma$-hole and the other is an electron-withdrawing group in order to increase the adjacent $\sigma$-hole depth. This design was also substantiated by calculating the electrostatic potential $(V)$ on focused regions of these molecules, so that local electron charge density, especially of $\sigma$-hole regions, could be anticipated.

A general strategy was thus designed for the synthesis of various ferrocenyl-based iodoalkynes 9-13 and chalcogenoalkynes 16-17 starting from 1,2- or 1,3disubstituted ferrocenes 1-2 (Scheme 1). The $\sigma$-hole donor atom (I, S or Se) would be introduced in the late stage from silyl-protected alkynes 4-5 and 6-8 through a deprotection-functionalization sequence which can be conducted in one or two steps. Starting from bromosubstituted ferrocenyl compounds $4 \mathbf{a}$ and $\mathbf{5 a}(\mathrm{X}=\mathrm{Br})$, the introduction of aryl and methyl groups would be carried out through Suzuki coupling or bromine/lithium exchange followed by electrophilic quenching. The alkyne function in derivatives 4-8 would be introduced by using a selective Sonogashira coupling with the readily available iodoferrocenyl derivatives 1-2.
In the frame of a rational design approach, the $V$ of iodo-, thio- and selenoethynylferrocenes 9a-c, 10b, 16a, and 17a were computed on a 0.002 au molecular isosurface $\left(V_{S}\right)$.

\section{Scheme 1. General strategy for the synthesis of ferrocenyl-based iodoalkynes 9-13 and chalcogenoalkynes 16-17.}
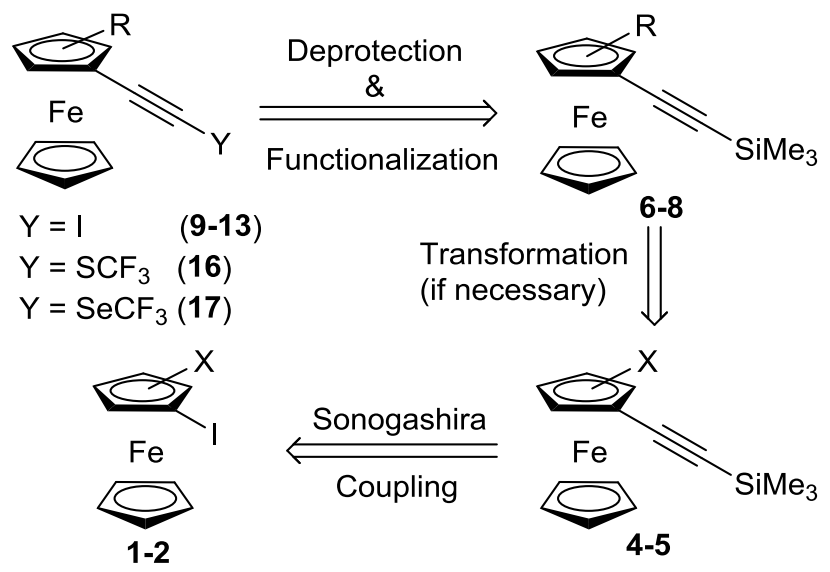

The $V_{\mathrm{S}}$ of pentafluorobenzenes 18-20, halobenzenes 21-23 and 25-30, haloferrocenes $\mathbf{1 b}$ and $\mathbf{3} \mathbf{a}-\mathbf{b}$, as well as nonsubstituted iodoethynylbenzene $\quad \mathbf{2 4}$ and iodoethynylferrocene $\mathbf{3 1}$ were computed as benchmarks in order to evaluate the impact of both ferrocenyl and ethynyl substructures on local electron charge density of the $\sigma$ hole regions. For this purpose, the $V_{\mathrm{S}}$ maxima $\left(V_{\mathrm{S}, \max }\right)$ on the $\sigma$-holes centred on I and $\mathrm{Ch}(\mathrm{S}, \mathrm{Se})$ atoms were compared (Table 1) in order to explore the effect of subtle structure modifications on $\sigma$-hole depth.

The geometry of all compounds listed in Table 1 was optimized using Density Functional Theory with B3LYP functional (completed with D3 dispersion corrections) and Def2TZVPP basis set. The local maxima of the electrostatic potential $\left(V_{S, \max }\right)$ values were calculated on the 0.002 a.u. isodensity surface (see Supporting Information for details).

As expected, these theoretical results confirmed the beneficial effect of the alkyne moiety on the iodine $\sigma$-hole depth (entry 4 vs 12 and 7 vs 19). The results also showed that the activation ability of the alkyne function toward iodine $\sigma$-hole is comparable and even slightly better than the effect of perfluorination (entry 10 vs 1). This effect can be increased by an additional electron-withdrawing halogen atom (entry 10 vs 11-13 and 16). It is worth noting that the obtained $V_{S \text {, max }}$ values for the series 24-27 and $\mathbf{3 0}$ are in good agreement with the donor/acceptor nature of substituents in other reports concerning similar iodoalkynebased structures. ${ }^{27,44-46}$ Interestingly, when the chlorine was placed in 3-position, the iodine $\sigma$-hole increased (entry 12 vs 16). The beneficial effects on iodine $\sigma$-hole due to the additional halogen atom (entry 17 vs 18-20) and its position (entry 19 vs 23) are also observed in the ferrocenyl iodoalkyne series. However, lower $V_{\mathrm{S} \text {,max }}$ values are always obtained for the ferrocenyl derivatives compared to the phenyl ones (entries 10-13 vs 17-20 and 16 vs $23)$, confirming the more electron-donating ability of ferrocene compared to phenyl. Nevertheless, the $V_{\mathrm{S} \text {,max }}$ values of ferrocenyl compounds $\mathbf{9 a - c}$ and $\mathbf{1 0 b}$ are still comparable to the one of iodopentafluorobenzene 18 (en- 
try 1 vs 18-20); therefore interesting $\sigma$-hole based properties can be expected with these compounds.

Table 1. $V_{S, \max }[\mathrm{kJ} / \mathrm{mol}]$ values calculated on I and $\mathrm{Ch} \sigma-$ holes (B3LYP-D3/Def2TZVPP) ${ }^{a}$

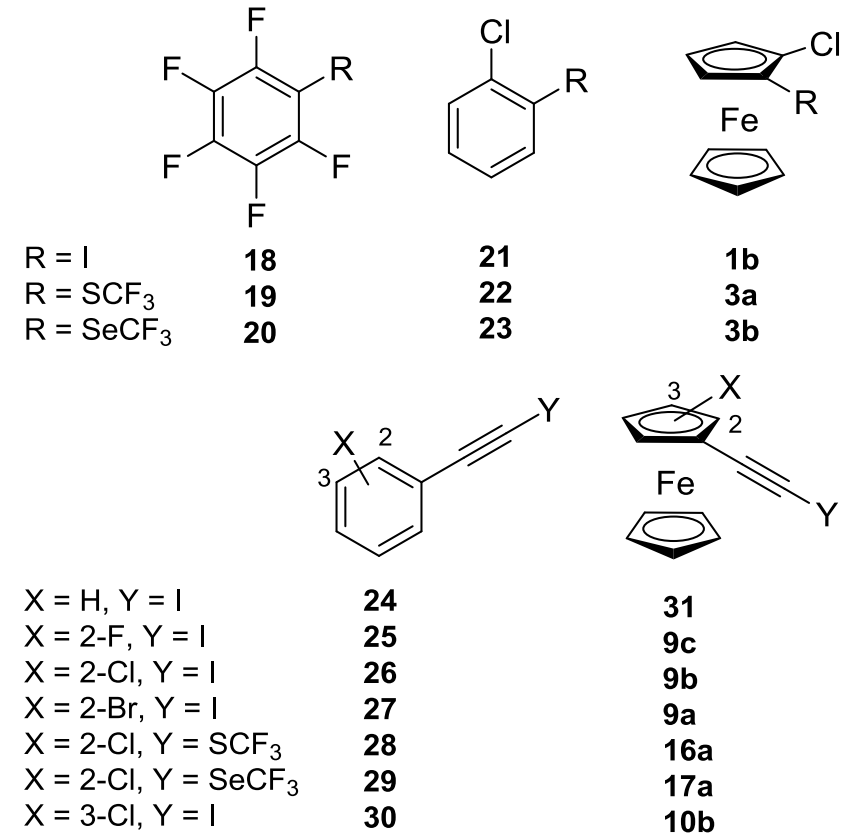

\begin{tabular}{|c|c|c|c|c|c|}
\hline \multirow[b]{2}{*}{ Entry } & \multirow[b]{2}{*}{ Compound } & \multicolumn{4}{|c|}{$V_{\mathrm{S}, \max }[\mathrm{kJ} / \mathrm{mol}]^{\mathrm{a}}$} \\
\hline & & $\mathbf{I}$ & $\begin{array}{c}\text { Ch }\left(\mathrm{C}_{\mathrm{Ar} / \mathrm{Fc}}-\right. \\
\mathrm{Ch})^{\mathrm{b}}\end{array}$ & $\begin{array}{l}\text { Ch (Cethynyl- } \\
\text { Ch) }\end{array}$ & 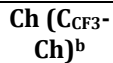 \\
\hline 1 & 18 & 181 & -- & -- & -- \\
\hline 2 & 19 & -- & 100 & -- & 140 \\
\hline 3 & 20 & -- & 136 & -- & 158 \\
\hline 4 & 21 & 122 & -- & -- & -- \\
\hline $5^{c}$ & 22 & -- & $54 / 56$ & -- & 94/- \\
\hline $6^{c}$ & 23 & -- & $87 / 87$ & -- & $113 / 33$ \\
\hline 7 & $1 \mathrm{~b}$ & 119 & -- & -- & -- \\
\hline $\mathbf{8}^{\mathrm{c}}$ & $3 a$ & -- & $47 / 51$ & -- & $-/ 81$ \\
\hline $9^{c}$ & $3 \mathbf{b}$ & -- & $81 / 86$ & -- & $-/ 101$ \\
\hline 10 & 24 & 183 & -- & -- & -- \\
\hline 11 & 25 & 187 & -- & -- & -- \\
\hline 12 & 26 & 188 & -- & -- & -- \\
\hline 13 & 27 & 189 & -- & & \\
\hline $14^{c}$ & 28 & -- & -- & $95 / 95$ & $97 / 106$ \\
\hline $15^{c}$ & 29 & -- & -- & $138 / 135$ & $124 / 131$ \\
\hline 16 & 30 & 194 & -- & -- & -- \\
\hline 17 & 31 & 176 & -- & -- & -- \\
\hline 18 & $9 c$ & 182 & -- & -- & -- \\
\hline 19 & $9 b$ & 182 & -- & -- & -- \\
\hline 20 & 9a & 182 & -- & & \\
\hline $21^{c}$ & $16 a$ & -- & -- & $78 / 83$ & $91 / 84$ \\
\hline $22^{c}$ & $17 a$ & -- & -- & $119 / 124$ & $115 / 110$ \\
\hline 23 & $10 \mathrm{~b}$ & 185 & -- & -- & -- \\
\hline
\end{tabular}

${ }^{a}$ Calculations were performed by using Gaussian09 Version D.01 program (see Supporting Information for details); ${ }^{b}$ corresponds to the hole along the $\mathrm{Cl}_{\mathrm{l}}-\mathrm{Ch}$ axis; ' ${ }^{\mathrm{C}}$ two conformations were observed for these compounds.
Regarding the chalcogen atoms, they possess two $\sigma$-holes, one on the elongation of the $\mathrm{C}_{\mathrm{CF}_{3}}-\mathrm{Ch}$ bond and one on the elongation of the $\mathrm{C}_{\mathrm{Ar} / \mathrm{Fc}}-\mathrm{Ch}$ or $\mathrm{C}_{\text {ethynyl- }} \mathrm{Ch}$ bond. As a matter of fact, in non-symmetrical compounds such as 22-23, 3a-b, 28-29 and 16a-17a, two conformations are observed depending on the position of the CF3 group with respect to the chlorine atom. Interestingly, in compounds 22, 23 and 3a-b (entries 5-6 and 8-9), the $V_{\mathrm{S}, \max }$ values along the $\mathrm{C}_{\mathrm{CF}_{3}-}$ Ch bond for the two conformers are completely different and in three cases, the $\sigma$-hole of one of the two conformers cannot be observed (entries 5, 8 and 9). This effect is due to the contribution of neighboring atoms on the analyzed molecular surface. For example, in the second conformation of compound 23, the expected selenium $\sigma$-hole opposite to $\mathrm{CF}_{3}$-Se bond is directly oriented toward the negative crown of the adjacent chlorine atom, leading to a smaller $V_{\mathrm{S}}$ value than in the first conformation where the same $\sigma$-hole points toward the exterior of the molecule. In the case of $\mathbf{3 b}$ this effect is even more pronounced since the expected $\sigma$-hole points toward an hydrogen atom of the neighboring cyclopentadienyl ring and appears buried inside the chosen molecular envelope and is thus not revealed onto this surface (see Fig. S26 in Supporting Information).

From the results, it can also be noted that the alkyne function also polarizes sulfur and selenium atoms, increasing $\sigma$-hole depth in both phenyl (for S: entry 5 vs 14; for Se: entry 6 vs 15) and ferrocenyl (for S: entry 8 vs 21; for Se: entry 9 vs 22) series. The calculations also confirmed the effect of shifting from sulfur to selenium in all the chalcogen series, for which the $\sigma$-hole depth always increases.

On the basis of $V_{\mathrm{S}}$ analysis, the alkyne substructure proved to be a powerful tool to polarize both iodine and chalcogens, generating $\sigma$-hole regions potentially able to promote the catalytic activity of ferrocenyl derivatives 913, 16, and 17.

Racemic synthesis. The starting substituted iodoferrocenes 1a-d and $\mathbf{2 a - c}$ are described in the literature and were prepared accordingly (Scheme 2). 47-49

Scheme 2. Starting substituted iodoferrocenes.
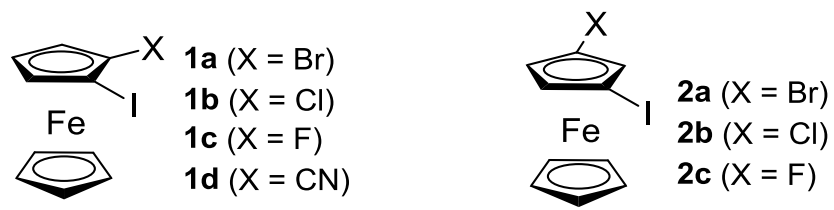

The ethynyl moiety was then introduced on 1,2- and 1,3iodoferrocenes 1-2 by Sonogashira coupling with trimethylsilylacetylene. Classical conditions, based on $\mathrm{PdCl}_{2}\left(\mathrm{PPh}_{3}\right)_{2}$ and $\mathrm{CuI}$ as catalysts and on diisopropylamine as base and solvent, ${ }^{50}$ provided variable results depending on the X substituent nature. (Scheme 3, Cond. A).

Optimization study performed on 1-bromo-2iodoferrocene 1 a revealed that 3 equivalents of trimethylsilylacetylene were necessary to achieve complete conversion. The expected compound $4 \mathbf{a}$ was thus isolated with $98 \%$ yield. However, the yield dropped significantly as the electron-withdrawing ability of the atom adjacent to iodine increased and when the substituent was 
placed in 3-position to iodine. Along with the expected compounds 4b-c or 5a-c, a substantial amount of the deiodinated starting material was isolated. In the case of 4d, the so-formed cyanoferrocene could not be removed by chromatography (Scheme S1 in Supporting Information for more details).

Scheme 3. Sonagashira coupling of iodoferrocenes 1-2.

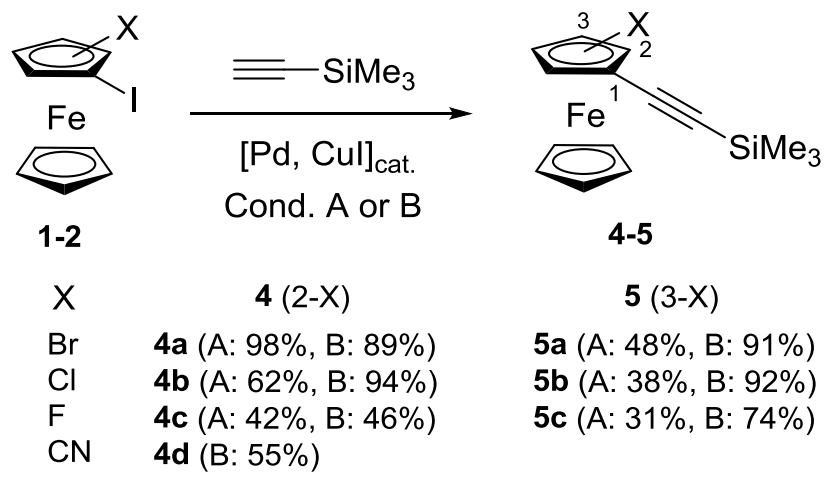

Cond. A: $\mathrm{PdCl}_{2}\left(\mathrm{PPh}_{3}\right)_{2}$ (5 mol\%), Cul (10 mol\%), $\equiv \mathrm{SiMe}_{3}$ (3 eq.), $i \mathrm{Pr}_{2} \mathrm{NH}, 60^{\circ} \mathrm{C}, 15 \mathrm{~h}$

Cond. B: $\mathrm{Pd}\left(\mathrm{Pt}-\mathrm{Bu}_{3}\right)_{2}$ (3 $\left.\mathrm{mol} \%\right)$, Cul (3 mol\%),

$\equiv-\mathrm{SiMe}_{3}$ (2 eq.), THF/iPr $2 \mathrm{NH}(3 / 1), \mathrm{rt}, 2 \mathrm{~h}$

The hydrodehalogenation reaction could be completely suppressed by using $\mathrm{Pd}\left(\mathrm{P} t-\mathrm{Bu}_{3}\right)_{2}$ previously described as a highly active catalyst in the Sonogashira reaction of 1,1'diiodoferrocene. ${ }^{51}$ Except for $4 c$, yields were significantly improved and compound $\mathbf{4 d}$ could be obtained pure after removing the unreacted starting material (Scheme 3, Cond. B).

To compare with the effect of the halogeno- or cyano substituents, neutral non-electron-withdrawing groups were also introduced on the ferrocenyl unit. The simple methyl group was selected, as well as two aryl groups, phenyl and the larger 2-naphthyl (Scheme 4). The introduction of the latter was readily achieved through Suzuki reaction.

Scheme 4. Arylation and methylation of bromoferrocenyl-acetylenes $4 a$ and $5 a$.
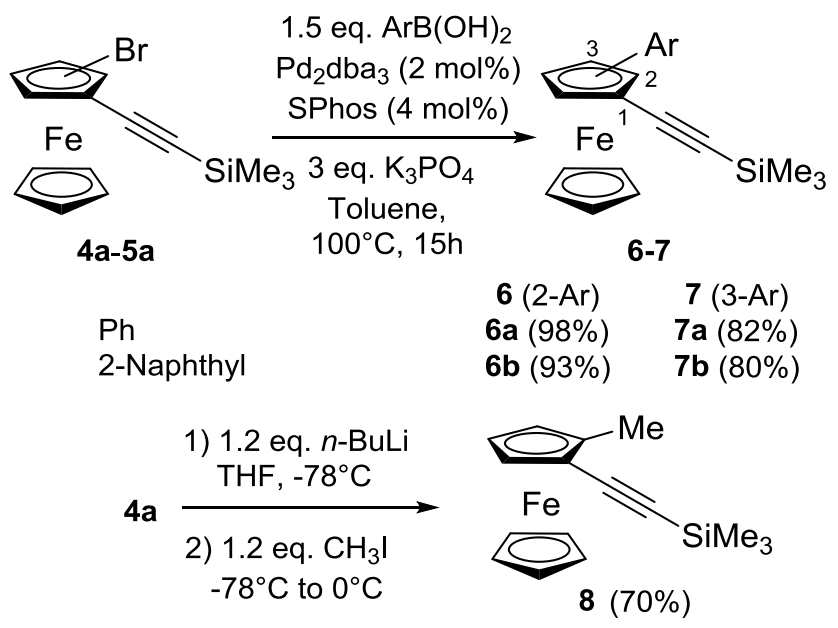

Coupling phenyl- and 2-naphthyl boronic acids with bromo-substituted ferrocenylalkynes $\mathbf{4 a}$ and $\mathbf{5 a}$ were efficiently performed by using 2-dicyclohexylphosphino- 2',6'-dimethoxybiphenyl (SPhos) as ligand and potassium phosphate as base in toluene at $100^{\circ} \mathrm{C} .{ }^{52}$ Indeed, good yields ranging from $80 \%$ to $98 \%$ were obtained for derivatives 6-7. The methyl group was introduced by addition of $n$-BuLi on compound $\mathbf{4 a}$ followed by quenching the lithiated ferrocenyl species. Derivative 8 was thus obtained with a good yield of $70 \%$ (Scheme 4 ).

For the synthesis of ferrocenyl iodoalkynes 9-13, we explored the possibility to perform in one step the trimethylsilyl (TMS) group removal and the iodination of compounds 4-8.

The combination of silver (I) fluoride and $\mathrm{N}$ iodosuccinimide (NIS) was already described for this purpose with a variety of TMS-protected alkynes. ${ }^{53}$ Although the expected iodoalkynes were obtained in all cases, the yields were generally low to moderate (Scheme 5, a). This could be due to oxidation of the ferrocene moiety by the silver salts present in the reaction mixture. ${ }^{54,55}$

Scheme 5. Preparation of ferrocenyl iodoalkynes 9-13 through deprotection-iodination of compounds 4-8.

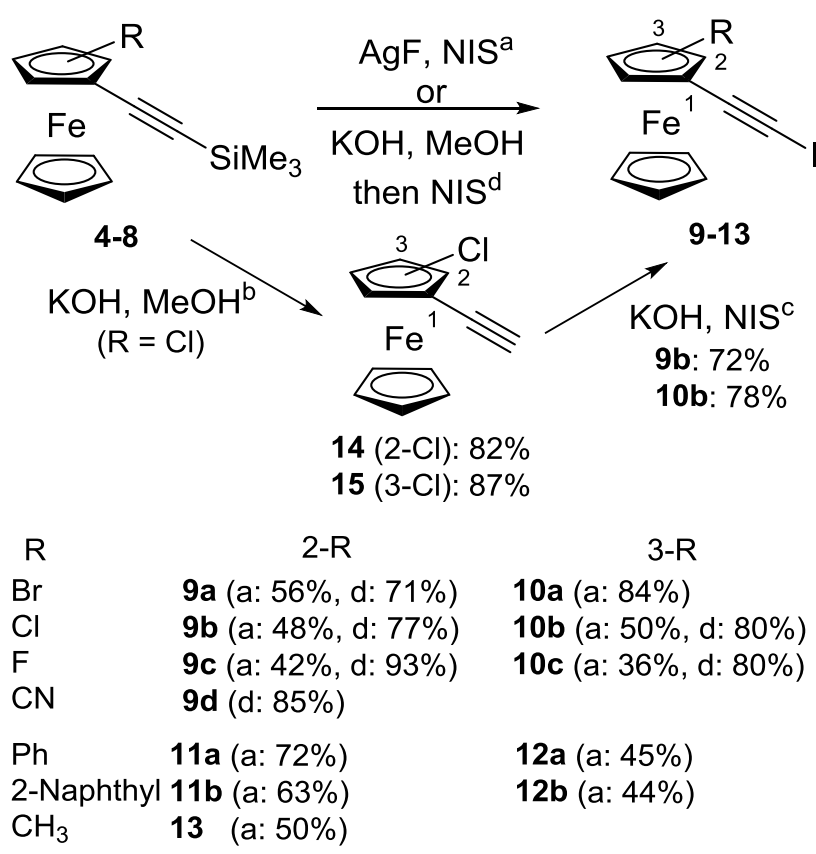

Conditions:

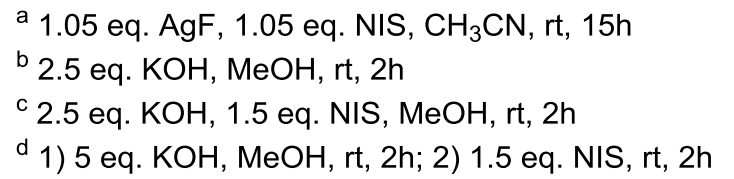

With the aim to avoid silver salts and to increase yields, a two-step procedure was tested. TMS-alkynes $\mathbf{4 b}$ and $\mathbf{5 b}$ were first deprotected with $\mathrm{KOH}$ in methanol at room temperature to give alkynes $\mathbf{1 4}$ and $\mathbf{1 5}$ with good yields (Scheme 5, b). These alkynes were then treated again with $\mathrm{KOH}$ before addition of NIS ${ }^{56}$ to give iodoalkynes $\mathbf{9 b}$ and 10b with good yields (Scheme 5, c). Since KOH is used in the two steps, a one-pot procedure was employed with $\mathbf{4 b}$ and $\mathbf{5 b}$, furnishing directly iodoalkynes $\mathbf{9 b}$ and $\mathbf{1 0 b}$ with yields superior to those of the two-step procedure. This protocol was therefore applied to TMS-alkynes $4 \mathbf{4}, \mathbf{4 c - d}$ 
and $\mathbf{5 c}$, increasing greatly the yields of the corresponding iodoalkynes 9a, 9c-d, and 10c (Scheme 5, d).

For the synthesis of chalcogenoalkynes 16 and 17, 2- and 3-chloroferrocenyl acetylenes $\mathbf{1 4}$ and $\mathbf{1 5}$ were functionalized through lithiation and electrophilic quenching with donors of $\mathrm{SCF}_{3}$ and $\mathrm{SeCF}_{3}$ groups. Alkyne deprotonation of $\mathbf{1 4}$ and $\mathbf{1 5}$ was performed with $n$-BuLi and the resulting lithioalkynes were trapped with $N$-methyl- $N$ (trifluoromethylsulfanyl)aniline ${ }^{57}$ to give thioalkynes 16a and 16b, and with the in situ generated $\mathrm{ClSeCF}_{3}{ }^{58}$ to furnish selenoalkynes $\mathbf{1 7} \mathbf{a}$ and $\mathbf{1 7} \mathbf{b}$. Unexpectedly, $\mathbf{1 7 b}$ was obtained as an inseparable mixture with chloroalkene 18. ${ }^{59}$ Therefore, the $\mathbf{1 7 b} / \mathbf{1 8}$ mixture was treated with an excess of $\mathrm{LiOH}$ in $\mathrm{DMSO}^{60}$ to deliver the pure compound $\mathbf{1 7 b}$ with a moderate overall yield (Scheme 6).

Scheme 6. Synthesis of ferrocenyl-based thioalkynes $16 a, b$ and selenoalkynes $17 a, b$
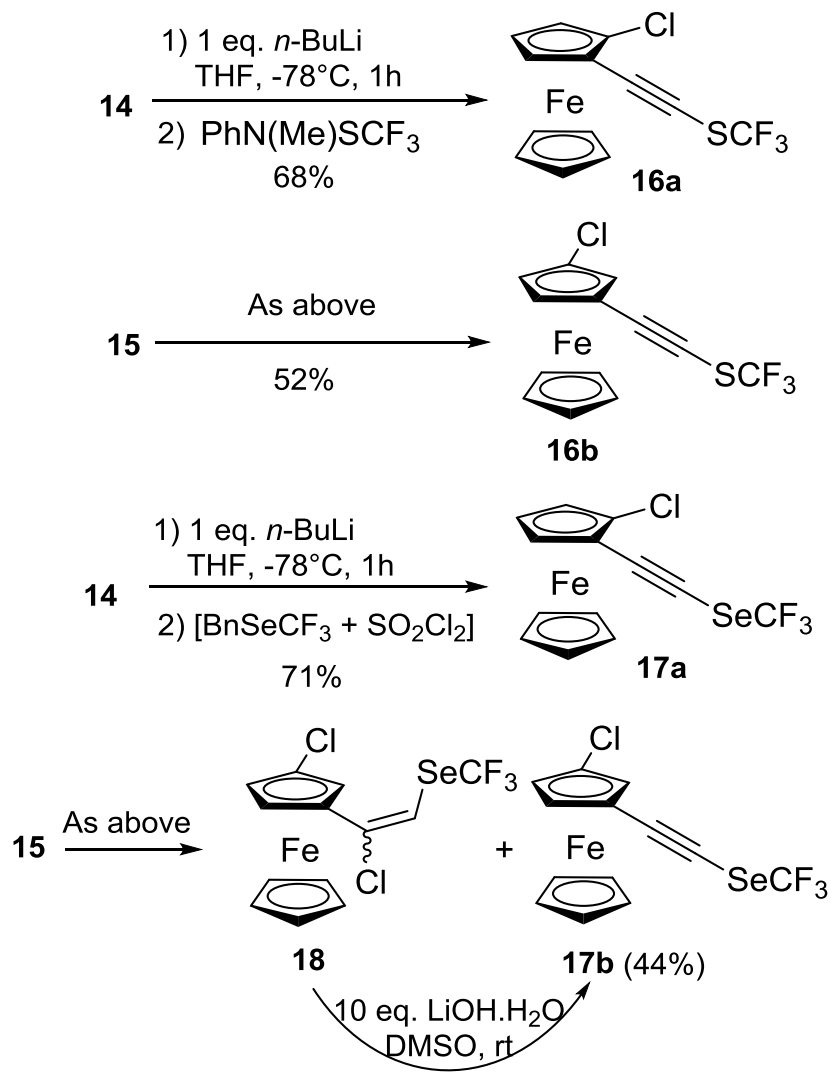

Evaluation of ferrocenyl iodo- or chalcogeno alkynes: $\mathrm{C}-\mathrm{Br}$ and thioamide activation. In order to evaluate the $\sigma$-hole donor properties in solution of the new ferrocenebased iodo- and chalcogeno-alkynes, we have considered two benchmark reactions: the Ritter reaction, ${ }^{61}$ allowing the transformation of benzhydryl bromide $\mathbf{3 2}$ to acetamide 33, and the synthesis of benzoxazole 36 from thioamide $3^{62}$ (Scheme 7). In order to study the influence of the substituent in both reactions, five compounds of the 2substituted ferrocenyl iodoalkyne family (9a-c and 11a-b) were tested. Moreover, the effects of the substituent position and the nature of the donor atom were also evaluated by using compounds $\mathbf{1 0 b}$ and $\mathbf{1 7 a}$ (Table 2).

Ritter-type reactions ${ }^{63}$ involve the nucleophilic substitution of alcohol, sulfate or halide group by acetonitrile or related nitriles, usually used as solvent. The resulting nitrilium is then hydrolyzed to the corresponding amide by added water. Depending on the leaving group nature, electrophilic assistance could facilitate the reaction and catalysis could be established. Lewis acids could act as such and some could catalyze such reactions. ${ }^{64}$ With $\sigma$-hole based organocatalysts and halogenated substrates, the Ritter reaction is not catalytic due to its mechanism, close to $S_{N} 1$ process. In this reaction, the $\sigma$-hole donor interacts with the bromine of the substrate (compound $\mathbf{3 2}$ here; Scheme 7) up to abstract it and the nucleophilic acetonitrile solvent replaces it. Nevertheless, the Ritter reaction allows reliable evaluation of the $\sigma$-hole donor ability in solution. ${ }^{31,43,65,66}$ All the ferrocenyl derivatives examined were able to efficiently promote the expected transformation, except for fluoro derivatives (Table 2).

\section{Scheme 7. XB or ChB activation of C-Br and thioamide}
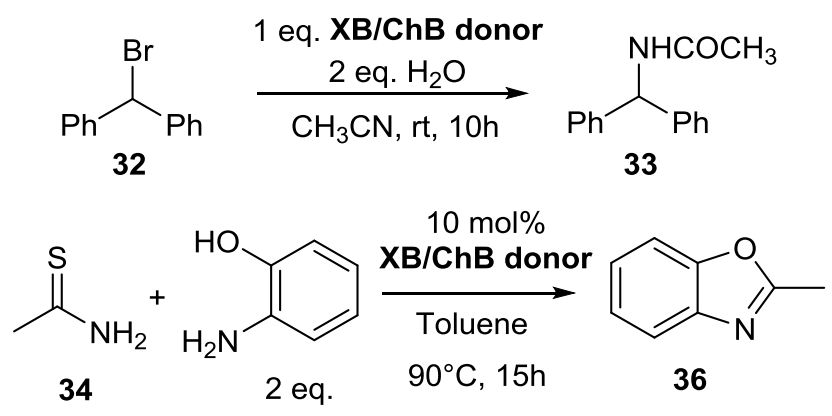

Table 2. Results of Ritter reaction and benzoxazole synthesis

\begin{tabular}{|c|c|c|c|c|}
\hline XB/ChB donor & $\mathrm{X} / \mathrm{Ch}$ & $\mathrm{R}$ & $\mathbf{3 3}(\%)^{\mathrm{a}}$ & $\mathbf{3 6}(\%)^{\mathrm{c}}$ \\
\hline $\mathbf{9 a}$ & $\mathrm{I}$ & $2-\mathrm{Br}$ & 100 & 72 \\
\hline $\mathbf{9 b}$ & $\mathrm{I}$ & $2-\mathrm{Cl}$ & 91 & 86 \\
\hline $\mathbf{1 0 b}$ & $\mathrm{I}$ & $3-\mathrm{Cl}$ & 94 & 64 \\
\hline 9c & $\mathrm{I}$ & $2-\mathrm{F}$ & 35 & 86 \\
\hline $\mathbf{1 1 a}$ & $\mathrm{I}$ & $2-\mathrm{Ph}$ & 100 & 97 \\
\hline $\mathbf{1 1 b}$ & $\mathrm{I}$ & $2-\mathrm{Naph}$ & 100 & 83 \\
\hline $\mathbf{1 7 a}$ & Se & $2-\mathrm{Cl}$ & $35^{\mathrm{b}}$ & $<5 \%$ \\
\hline
\end{tabular}

a $1 \mathrm{H}$ NMR conversions obtained by integration of peaks at $6.44 \mathrm{ppm}$ (starting material) and at $5.77 \mathrm{ppm}$ (product) in $\mathrm{CD}_{3} \mathrm{CN}$ (ref. 31); b $60 \%$ conversion after $24 \mathrm{~h}$; ${ }^{\mathrm{c}}{ }^{1} \mathrm{H}$ NMR yields by using DMF as an internal standard (ref. 30).

In the 2-haloferrocenyl iodoalkyne series 9a-c, high conversions were obtained with the 2-bromo and 2-chloro derivatives $\mathbf{9 a}$ and $\mathbf{9 b}$ whereas a low conversion of $34 \%$ was observed with the 2 -fluoro derivative 9 c. This difference in reactivity was unexpected with regard to the calculated $V_{\mathrm{s} \text {,max }}$ values (Table 1, entries 18-20). Comparison of the 2 - and 3 -chloro derivatives $\mathbf{9 b} / \mathbf{1 0 b}$ showed that the position of the halogen on the ferrocene moiety has very little impact on the reactivity, but in agreement with their slightly different $V_{\mathrm{s}, \max }$ values (Table 1 , entry 23 vs 19 ). Surprisingly, the 2-aryl ferrocenyl iodoalkyne 11a-b were as effective as the 2- bromo derivative $\mathbf{9 a}$, but more than the 2-chloro analog $\mathbf{9 b}$, despite the stronger electronwithdrawing character of the latter.

These results revealed that the iodine $\sigma$-hole is well activated by the alkyne function and that the substituent on the ferrocene moiety only has moderate influence on reac- 
tivity, except for the strongly electron-withdrawing fluoride. In contrast, the nature of the $\sigma$-hole donor has a strong influence on the reaction efficiency. Indeed, with the seleno derivative $\mathbf{1 7 a}$, the reaction proved to be slower giving only $35 \%$ conversion after $10 \mathrm{~h}$ and $60 \%$ conversion after $24 \mathrm{~h}$.

Benzoxazoles are important compounds owing to their various biological activities and their roles in fluorescent and/or electroluminescent materials. ${ }^{67}$ In 2016, Matsuzawa and coll. have shown that iodoalkynes are able to catalyze the synthesis of benzoxazole from thioamides and 2aminophenol based on iodine---sulfur interaction. ${ }^{30}$ This reaction is thus worth for comparison (Table 2). Interestingly, all the ferrocenyl iodoalkynes were able to act as catalyst and gave the expected benzoxazole 36 . High yields were obtained with the 2-chlorinated and 2-fluorinated compounds $\mathbf{9 b}$ and $9 \mathbf{c}$ whereas a lower yield was obtained with the 2-brominated analog 9a. In contrast to the Ritter results, the 3 -chloro catalyst $\mathbf{1 0 b}$ proved to be less effective, as the yield significantly dropped (64 vs $86 \%$ ). As for the Ritter reaction, the aryl-substituted ferrocenyl iodoalkynes 11a and 11b were very efficient, giving high to quantitative yields of benzoxazole 36 . The selenium derivative 17a proved again to be less efficient than the iodinated derivatives since almost no benzoxazole was formed during the reaction.

In summary, regarding the results of Table 2, the effects of nature and position of the halogen substituent on the activity of the iodoalkynes as activators or catalysts in the considered reactions are very difficult to analyze. It is however clear that the aryl-substituted compounds $\mathbf{1 1 a}$ and 11b are very active in both reactions which open the possibility to use them or other analog substituents in asymmetric catalysis.

Asymmetric synthesis of ferrocenyl iodoalkynes. Considering the above results, we decided to focus only on the synthesis of enantiopure ferrocenyl iodoalkynes. As shown through the racemic synthesis, compounds $\mathbf{4 a}$ and $\mathbf{5 a}$ are key intermediates for the synthesis of ferrocenyl iodoalkynes bearing substituents of different nature. For the 1,2-disubstituted series, we considered the preparation of enantiopure $\left(S_{\mathrm{Fc}}\right)-\mathbf{1 a}$ as described in the literature ${ }^{68}$ but the yields and the enantiomeric excess we obtained were unsatisfactory. Another useful enantiopure 1,2substituted ferrocenyl synthon, the $\left(S_{S}, S_{\mathrm{Fc}}\right)$ sulfinylferrocenyl boronic acid, attracted our attention but it is suited only for the preparation of arylsubstituted ferrocenes. ${ }^{69}$

We finally turned our attention to the Kagan's method which delivers enantiopure 2-substituted ferrocenecarboxaldehydes. ${ }^{70}$ In particular, 2-bromo ferrocenecarboxaldehyde $\left(S_{\mathrm{Fc}}\right)-36$ was prepared ${ }^{71}$ and transformed to the alkyne $\left(S_{\mathrm{Fc}}\right)-37$ through a SeyferthGilbert homologation with Ohira-Bestmann reagent $38 .{ }^{72} \mathrm{~A}$ TMS group was then introduced on the alkyne to give the key compound $\left(S_{\mathrm{Fc}}\right)$-4a. Concerning the 1,3-disubstituted series, enantiopure compound 5 a was not available but the iodinated analog $\left(S_{\mathrm{Fc}}\right)$-39 was described in the literature. ${ }^{73}$ It was then transformed to key compound $\left(S_{\mathrm{Fc}}\right) \mathbf{- 4 1}$ through alkyne $\left(S_{\mathrm{Fc}}\right)$-40 (Scheme 8).
Scheme 8. Synthesis of enantiopure key compounds $\left(S_{\mathrm{Fc}}\right)-4 \mathrm{a}$ and $\left(S_{\mathrm{Fc}}\right)-41$.

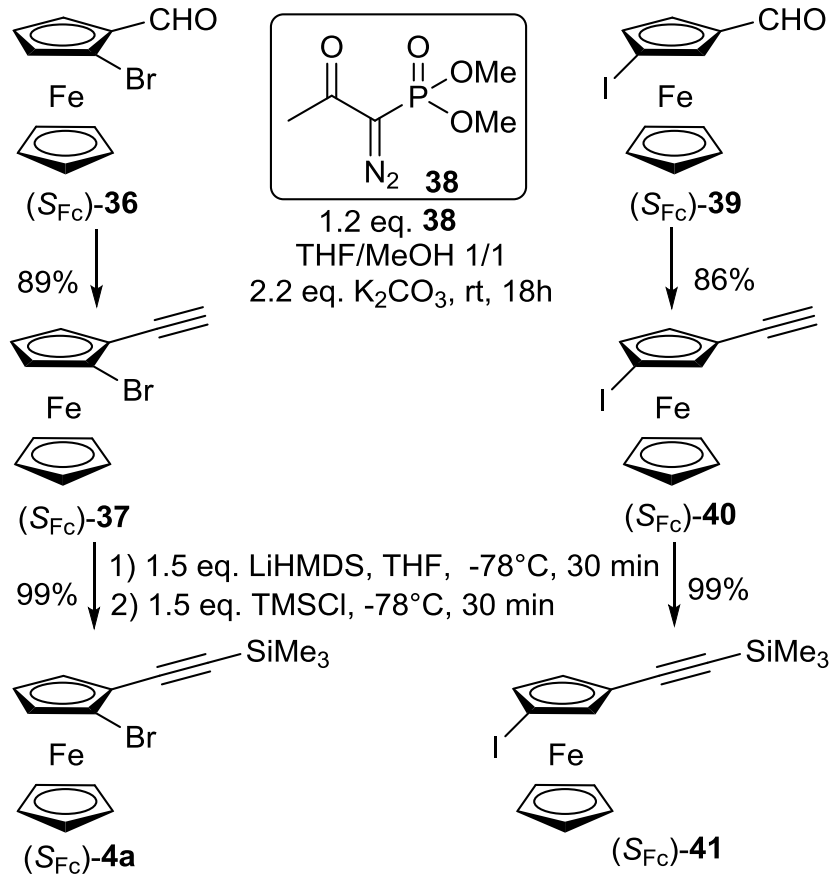

On one hand, when applying the experimental conditions set up for the Suzuki coupling of related compounds (see Scheme 4), compounds $\left(S_{\mathrm{Fc}}\right)-\mathbf{4 a}$ and $\left(S_{\mathrm{Fc}}\right) \mathbf{- 4 1}$ were very efficiently transformed to $\left(S_{\mathrm{Fc}}\right)-\mathbf{6} \mathbf{a}-\mathbf{b}$ and $\left(S_{\mathrm{Fc}}\right)-\mathbf{7} \mathbf{a}-\mathbf{b}$, respectively (Scheme 9, left). On the other hand, halogenlithium exchange followed by electrophilic quenching afforded differently substituted derivatives. Starting from $\left(S_{\mathrm{Fc}}\right)-4 \mathrm{a}$, quenching the lithiated species with MeI, $N$ fluorobenzenesulfonimide (NFSI) and $p$-toluenesulfonyl cyanide $(\mathrm{TsCN})$ delivered compounds $\left(R_{\mathrm{Fc}}\right)-\mathbf{8},\left(S_{\mathrm{Fc}}\right)-4 \mathrm{c}$ and $\left(S_{\mathrm{Fc}}\right)-4 d$, respectively. Addition of $\alpha, \alpha^{\prime}$-dibromoxylene to the lithiated intermediate obtained from $\left(S_{\mathrm{FC}}\right) \mathbf{- 4 1}$ furnished $\left(S_{\mathrm{Fc}}\right)$-5a which contained small amounts of inseparable impurities (Scheme 9, right).

Finally, the deprotection-iodination methods (see Scheme 5) were applied to all enantiopure/enantioenriched ferrocenyl trimethylsilylethynes. This sequence furnished diversely substituted ferrocene iodoethynes, i.e. $\left(S_{\mathrm{Fc}}\right)$ 9a,c,d, $\left(S_{\mathrm{Fc}}\right)-10 \mathbf{a},\left(S_{\mathrm{Fc}}\right)-11 \mathbf{a}, \mathbf{b}, \quad\left(S_{\mathrm{Fc}}\right)-12 \mathbf{a}, \mathbf{b}$ and $\left(R_{\mathrm{Fc}}\right)-\mathbf{1 3}$ (Scheme 10).

Scheme 9. Functionalization of $\left(S_{\mathrm{Fc}}\right)-4 \mathrm{a}$ and $\left(S_{\mathrm{Fc}}\right)-41$ 


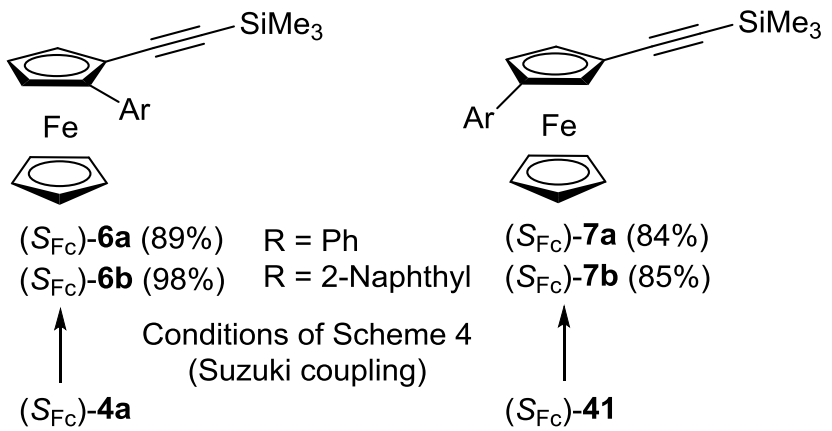

\begin{tabular}{|l|l} 
1) 1.2 eq. $n$-BuLi, & 1) 2.2 eq. $t$-BuLi \\
THF, $-78^{\circ} \mathrm{C}, 1 \mathrm{~h}$ & THF, $-78^{\circ} \mathrm{C}$ \\
2) $\mathrm{E}^{+}(\mathrm{Mel}$ for $\mathrm{R}=\mathrm{Me}, \mathrm{NFSI}$ & 2) $p\left(\mathrm{BrCH}_{2}\right)_{2} \mathrm{C}_{6} \mathrm{H}_{4}$ \\
for $\mathrm{R}=\mathrm{F}, \mathrm{TsCN}$ for $\mathrm{R}=\mathrm{CN})$ & $\downarrow$
\end{tabular}

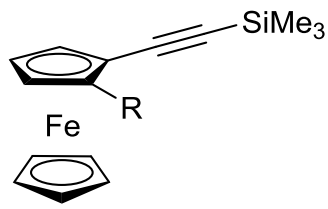

$\left(R_{\mathrm{Fc}}\right)-8(\mathrm{R}=\mathrm{Me}, 73 \%)$

$\left(S_{\mathrm{Fc}}\right)-4 \mathrm{c}(\mathrm{R}=\mathrm{F}, 71 \%)$

$\left(S_{\mathrm{Fc}}\right)-4 \mathrm{~d}(\mathrm{R}=\mathrm{CN}, 41 \%)$

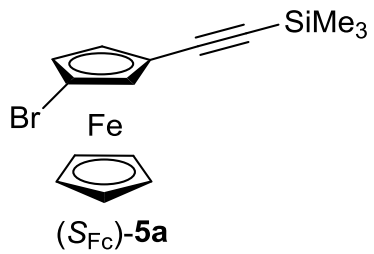

The enantiomeric purity of compounds $\left(S_{\mathrm{Fc}}\right)-\mathbf{9 a}, \mathbf{c}, \mathbf{d},\left(S_{\mathrm{Fc}}\right)$ 10a, $\left(S_{\mathrm{Fc}}\right)-11 \mathbf{a}, \mathbf{b},\left(S_{\mathrm{Fc}}\right)-\mathbf{1 2} \mathbf{a}, \mathbf{b}$ and $\left(R_{\mathrm{Fc}}\right)-13$ was determined through high-performance liquid chromatography (HPLC) on polysaccharide-based chiral columns. For compound 9a,d, 10a, 11b, 12a,b and 13, the proper combination of column and mobile phase was optimized allowing for obtaining baseline enantioseparations. For compounds 9c and 11a partial separation was only achievable. For all compounds, enantiomeric excesses $\geq 92.8 \%$ were measured (Scheme 10, see Table S1 and Fig. S1-S9 in Supporting Information for details).

Scheme 10. Synthesis of enantiopure ferrocenyl iodoalkynes

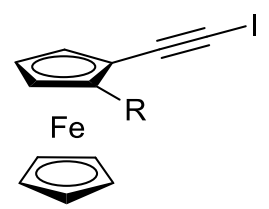

$\left(S_{\mathrm{Fc}}\right)-9 \mathrm{a}(\mathrm{R}=\mathrm{Br}, 98.3 \%$ ee $)$. Cond. a: $53 \%$; Cond. d: $87 \%$

$\left(S_{\mathrm{Fc}}\right)-9 \mathrm{c}(\mathrm{R}=\mathrm{F}, \mathbf{9 2 . 8 \%}$ ee). Cond. a: $51 \%$

$\left(S_{\mathrm{Fc}}\right)-9 \mathrm{~d}(\mathrm{R}=\mathrm{CN}, \mathbf{9 8 . 7 \%}$ ee $)$. Cond. a: $77 \%$

$\left(S_{\mathrm{Fc}}\right)-11 \mathrm{a}(\mathrm{R}=\mathrm{Ph}, 96.8 \%$ ee) . Cond a.: $59 \%$

$\left(S_{\mathrm{Fc}}\right)-11 \mathrm{~b}(\mathrm{R}=2-\mathrm{Naph}, 97.4 \%$ ee $)$. Cond. a: $67 \%$

$\left(R_{\mathrm{FC}}\right)-13(\mathrm{R}=\mathrm{Me}, 97.3 \%$ ee). Cond. a: $39 \%$; Cond. d: $73 \%$

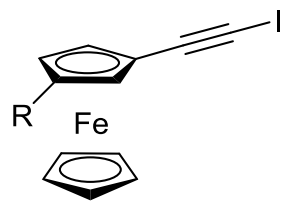

$\left(S_{\mathrm{FC}}\right)-10 \mathrm{a}(\mathrm{R}=\mathrm{Br}, 93.7 \%$ ee). Cond. a: $38 \%$ (after 2 steps)

$\left(S_{\mathrm{Fc}}\right)-12 \mathrm{a}(\mathrm{R}=\mathrm{Ph}, 99.9 \%$ ee $)$. Cond. a: $56 \%$

$\left(S_{\mathrm{FC}}\right)-12 \mathrm{~b}(\mathrm{R}=2-\mathrm{Naph}, 99.9 \%$ ee $)$. Cond. a: $49 \%$;

Cond. d: $62 \%$
Solid state analysis. With these racemic and chiral ferrocenyl iodoethynes in hand, their $\sigma$-hole donor property in the solid state was investigated by X-ray diffraction analysis (XRD) when possible. Crystal structures were determined by single crystal XRD for a selected number of compounds. Hirshfeld molecular surfaces were computed for these structures (excepted for 9c which presents a disorder linked to symmetry) and actual surface contacts were compared to equiprobable contacts in order to derive the enrichment ratios (E)..$^{74}$ As seen in Table S2 (see Supporting Information), Fe atoms in these ferrocenyl compounds are almost fully buried between the cyclopentadienyl rings, offering a very small contribution to the total molecular surface; thus variations of this small surface between actual and equiprobable contacts are meaningless and not discussed. An enrichment ratio $\mathrm{E}$ larger (respectively smaller) than 1 means that the considered contact is enriched (respectively impoverished) in the actual crystal structure compared to the situation of equiprobable contacts. It can be noted (Tables S3-S10) that despite the richness of aromatic groups in the studied compounds, no $\pi \cdots \pi$ interaction is observed, carbon $\cdots$ carbon contacts being clearly under-represented $(\mathrm{E}(\mathrm{C} \cdot \mathrm{C})=0.7$ $0.8)$, excepted for $\left(S_{\mathrm{Fc}}\right)-12 \mathrm{a}$ in which the phenyl groups stacks in somewhat long $\pi \cdots \pi$ contact $(E(C, C)=1.06$; intercentroid distance of $4.187 \AA$; t tilt angle of $\left.23.96^{\circ}\right)$. Whereas $\mathrm{H} \cdots \mathrm{H}$ contacts are as well under-represented, contacts of hydrogen atoms with carbon and iodine atoms are overrepresented (excepted in 13 with $\mathrm{E}(\mathrm{H}, \mathrm{I})=0.97)$.

In all obtained crystal structures, I...C XBs are observed between the electropositive $\sigma$-hole of the iodine atom and electron rich $\pi$ clouds (Tables S3-S10 and S11). Interestingly, the XB acceptors vary, and can be the alkyne carbon atoms ${ }^{75}\left(\left(S_{\mathrm{Fc}}\right)-\mathbf{1 2} \mathbf{a},\left(R_{\mathrm{Fc}}\right)-\mathbf{1 3},\left(S_{\mathrm{Fc}}\right)-\mathbf{9 a}\right)$, the cyclopentadienyl rings bearing the alkyne group $\left(13,\left(S_{\mathrm{Fc}}\right)-11 \mathbf{a},\left(S_{\mathrm{Fc}}\right)-\mathbf{1 1} \mathbf{b}\right)$, the unsubstituted cyclopentadienyl rings ${ }^{76}\left(\mathbf{9 c},\left(S_{\mathrm{Fc}}\right)-9 \mathrm{c}\right)$ or the naphthyl group (11b). The negatively charged belts usually found around polarized heavy halogen atoms (see Supporting Information) are not involved as $\sigma$-hole acceptors in these structures, thus no halogen ...halogen bonds are evidenced for these compounds. Indeed, as can be seen for example on Fig. S29 (compound 9b) the ethynyl group offers more negative $V_{\mathrm{s}}$ than the bonded iodine atom itself.

These halogen interactions are forming infinite corrugated molecular chains in most of the structures $\left(\mathbf{9 c}, \mathbf{1 1 b},\left(R_{\mathrm{Fc}}\right)-\right.$ 13, $\left.\left(S_{\mathrm{Fc}}\right)-9 \mathbf{a},\left(S_{\mathrm{Fc}}\right)-9 \mathrm{c},\left(S_{\mathrm{Fc}}\right)-11 \mathrm{a},\left(S_{\mathrm{Fc}}\right)-11 \mathbf{b},\left(S_{\mathrm{Fc}}\right)-12 \mathbf{a}\right)$ (Fig. 1 and S10-S15). These chains stack to form planes which then interact through numerous $\mathrm{H} \cdots \mathrm{C}$ contacts to form $3 \mathrm{D}$ structures. Further $\mathrm{H} \cdots \mathrm{F}$ and $\pi \cdots \pi$ contacts can be noticed in respectively $\left(S_{\mathrm{Fc}}\right)-\mathbf{9 c}$ and $\mathbf{9 c}$, and in $\left(S_{\mathrm{Fc}}\right)$-12a (see Supporting Information).

One can distinguish two types of such planes among the structures which can be grouped in two families. In the first one the infinite chains are relatively separated $\left(\left(S_{\mathrm{Fc}}\right)-\right.$ 9a, $\left(R_{\mathrm{Fc}}\right)-13$, associated with relative large in-plane area per molecule) but in the second family these chains are more intimately nested and these structures have a relative small in-plane area per molecule $\left(\left(S_{\mathrm{Fc}}\right)-\mathbf{1 1} \mathbf{a},\left(S_{\mathrm{Fc}}\right)-\mathbf{1 1} \mathbf{b}\right.$, 11b, $\left.\left(S_{\mathrm{Fc}}\right)-12 \mathbf{a},\left(S_{\mathrm{Fc}}\right)-9 \mathrm{c}, 9 \mathbf{c}\right)$ (Table $\left.S 11\right)$. 

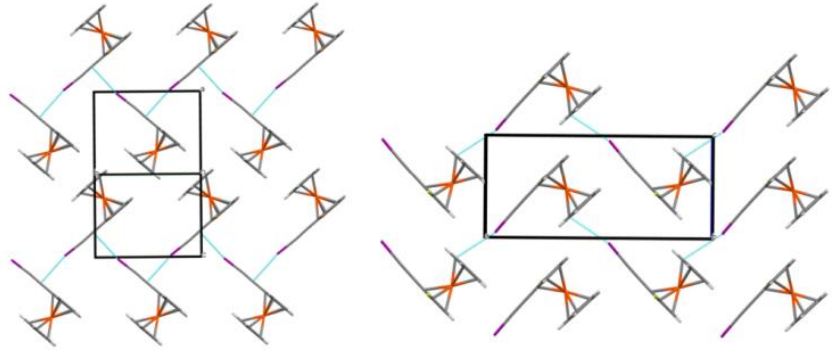

Figure 1. Planes containing the stacking of chains made of I $\cdots$ C halogen bonds (highlighted in cyan) in $\left(S_{\mathrm{Fc}}\right)-9 a$ (left, (101) plane) and in $\left(S_{\mathrm{Fc}}\right)-9 c$ (right, $(010)$ plane).

The thickness of the planes depends on the $\mathrm{R}$ substituent adjacent to the iodoalkyne functionality (Fig. S16), and the thinner is obtained for the smallest $\mathrm{R}$ group (9c and $\left(S_{\mathrm{Fc}}\right)$ 9c where $\mathrm{R}=\mathrm{F}$ ). The thickness also depends on the molecular orientation relative to the plane, with for example $\left(S_{\mathrm{Fc}}\right)$-11b and 11b where $\mathrm{R}=$ naphthyl exhibiting $\sim 30 \%$ plane width difference (Table S11).

The two members of the first family are isostructural $\left(\left(R_{\mathrm{Fc}}\right)-13\right.$ and $\left.\left(S_{\mathrm{Fc}}\right)-9 a\right)$, differing by $\mathrm{Me} / \mathrm{Br}$ substitution only. In the second family, the structures offer different level of similarities. $\left(S_{\mathrm{Fc}}\right)-\mathbf{1 1} \mathbf{a}$ and $\left(S_{\mathrm{Fc}}\right) \mathbf{- 1 1} \mathbf{b}$ both crystallize in $P 2{ }_{1} 2{ }_{1} 2_{1}$ space group with similar $a$ and $b$ unit cell parameters; these two structures are not strictly isostructural but nevertheless share common packing characteristics, both having very similar (001) molecular packing planes (Fig. S10, S11 and S17) formed by the stacking of the infinite I $\cdots$ C XBs chains (Table S11). The main difference between the crystal structures of these two compounds is then the packing of their (001) planes along the [001] direction, where one of the two structures can be deduced from the other by a translation of half the $b$ unit cell parameter. The larger difference in $c$ unit cell parameters arises from the fact that the aromatic rings are oriented along the [001] direction (Fig. S18).

$\left(S_{\mathrm{Fc}}\right)$-11a and $\left(S_{\mathrm{Fc}}\right)-12 \mathrm{a}$ are isomers, differing by the position of the phenyl group on the substituted cyclopentadienyl ring. Although these two structures display similar in-plane area per molecule (Table S11) their molecular planes containing the I...C motif differ by the orientations of the molecules within them (Fig. S10 and S13), and to somewhat different plane thicknesses (Table S11), making these two structures less superimposable than are $\left(S_{\mathrm{Fc}}\right)$-11a and $\left(S_{\mathrm{Fc}}\right)-\mathbf{1 1 b}$ (phenyl / naphthyl substitution).

$\left(S_{\mathrm{Fc}}\right)-9 \mathrm{c}$ and 9c crystallize in $P 2{ }_{1} 2_{1} 2_{1}$ and Pnma space groups, respectively. Their crystal structures only differ by the ordering of the fluorine position in enantiopure $\left(S_{\mathrm{Fc}}\right)$ 9c with respect to the $\mathrm{F} / \mathrm{H}$ site position disorder observed for the racemic $9 \mathbf{c}$.

$\left(S_{\mathrm{Fc}}\right)$-11b and its racemic counterpart $\mathbf{1 1 b}$ have also similar crystal packing to some extent. Although the molecular orientations differ leading to different plane thicknesses (Table S11), the more pronounced inter-plane penetration found in $\left(S_{\mathrm{Fc}}\right)$-11b leads finally to similar packing when considering the barycenter of ferrocenyl groups (Fig. S20).

Beside these eight crystal structures sharing similar molecular plane packing, the methyl-substituted derivative $\mathbf{1 3}$ exhibits an interesting further level of sophistication in its structure. Indeed, the halogen I $\cdots$ C interactions form interpenetrated helices of reversed chirality parallel to [010] direction (Fig. 2).
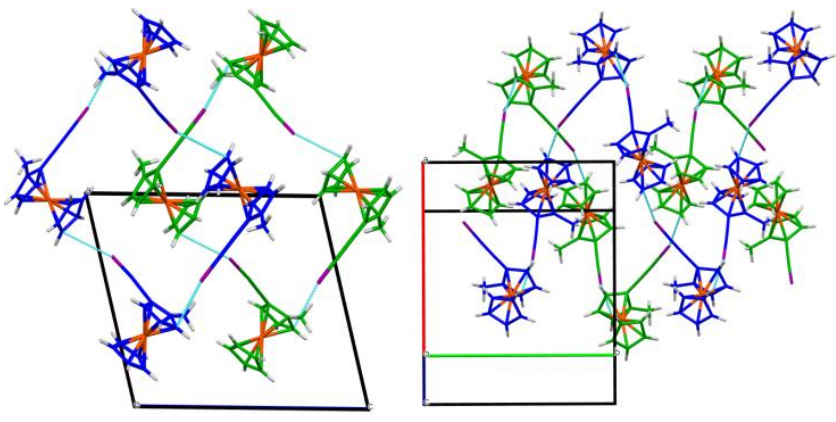

Figure 2. Views along [010] (left) and [001]* (right) of the infinite chains made of I...C halogen bonds (shown in dashed cyan) forming interpenetrating helices (highlighted in blue and green) in 13.

\section{CONCLUSION}

Two series of chiral $\sigma$-hole bond donors based on the ferrocenyl ethynyl scaffold were prepared and studied. In these systems, the direct attachment of the donor atoms (I, $\mathrm{S}, \mathrm{Se}$ ) to the alkyne function allows increasing their $\sigma$-hole depth. Representative compounds of each series of these new chiral $\sigma$-hole bond donors were used in solution for the activation of either a $\mathrm{C}-\mathrm{Br}$ bond in a Ritter reaction or a thioamide for the synthesis of benzoxazole. Whereas the Se-based compound furnished low or no conversion, the ferrocenyl iodoalkyne derivatives generally showed a very good activity in both reactions. Therefore, in view of developing enantiopure XB-based organocatalysts, the asymmetric synthesis of 1,2- and 1,3-disubstituted ferrocenyl iodoalkynes was performed with functional group introduction in 2- or 3- positions of different nature. Crystal structures of some derivatives in racemic or enantiopure forms were analyzed, confirming their good $\sigma$-hole bond donor property also in the solid state. Indeed, several intermolecular contacts between the electropositive $\sigma$-hole of the iodine atom and electron rich $\pi$ clouds were noticed, such as the $\mathrm{C}-\mathrm{C}$ triple bond and the $\mathrm{Cp}$ ring. The search of asymmetric reactions catalyzed by appropriately decorated enantiopure ferrocenyl iodoalkynes is currently underway in our laboratory.

\section{EXPERIMENTAL SECTION}

General Information. Proton $\left({ }^{1} \mathrm{H}\right.$ NMR) and carbon $\left({ }^{13} \mathrm{C}\right.$ NMR) nuclear magnetic resonance spectra were recorded on the following 300,400 , or $500 \mathrm{MHz}$ instruments. The chemical shifts are given in parts per million (ppm) on the delta scale. The solvent peak was used as reference values. For ${ }^{1} \mathrm{H}$ NMR: $\mathrm{CDCl}_{3}=7.26$ ppm. For ${ }^{13} \mathrm{C}$ NMR: $\mathrm{CDCl}_{3}=77.16 \mathrm{ppm}$. Data are presented as follows: chemical shift, multiplicity $(\mathrm{s}=$ singlet, $\mathrm{d}=$ doublet, $\mathrm{t}=$ triplet, $\mathrm{q}=$ quartet, quint $=$ quintet, $\mathrm{m}=$ multiplet, $\mathrm{b}=$ broad), integration, and coupling constants $(\mathrm{J} / \mathrm{Hz})$. High-resolution mass spectra (HRMS) data were recorded on a micrOTOF spectrometer equipped with an orthogonal electrospray interface (ESI). $[\alpha]_{D}$ values were measured at the sodium D-line on a JASCO J-815 CD spectropolarimeter, in $\mathrm{CHCl}_{3}$ in a quartz cuvette $(1 \mathrm{~cm})$ at $20^{\circ} \mathrm{C}$. Melting points were obtained in open capillary tubes and are uncorrected. Analytical thin layer chromatography (TLC) was carried out on silica gel 60 F254 plates with visualization by 
ultraviolet light. Reagents and solvents were purified using standard means. Tetrahydrofuran (THF) was distilled from sodium metal/benzophenone and used freshly. Anhydrous toluene, acetonitrile, and $\mathrm{MeOH}$ were obtained by passing through activated alumina under a positive pressure of argon using GlassTechnology GTS100 devices. Diisopropylamine was distilled over $\mathrm{CaH}_{2}$ and stored over $\mathrm{KOH}$, under an argon atmosphere. Anhydrous reactions were carried out in flame-dried glassware and under an argon atmosphere. All other chemicals were used as received.

Computational Details. The 3D structures of selected compounds (see Table 1) were optimized at the DFT level of theory using the B3LYP functional (completed with D3 dispersion corrections) and the Def2TZVPP basis set. Conformations were searched by scanning the corresponding degree of freedom and frequency calculations were performed in order to check that true energy minima were obtained. Computation of electrostatic potential mapped on 0.002 a.u. electron density isosurfaces and search for extrema $V_{\mathrm{S} \text {,max }}$ were performed with AIMAll77 and MultiWfn programs. ${ }^{78,79}$

HPLC on chiral stationary phase. An Agilent Technologies (Waldbronn, Germany) 1100 Series HPLC system (high-pressure binary gradient system equipped with a diode-array detector operating at multiple wavelengths $(220,254,280 \mathrm{~nm})$, a programmable autosampler with a $20 \mu \mathrm{L}$ loop, and a thermostated column compartment) was employed for analytical enantioseparations. Data acquisition and analyses were carried out with Agilent Technologies ChemStation Version B.04.03 chromatographic data software. The UV absorbance is reported as milliabsorbance units (mAU). Lux Cellulose-1 (coated cellulose tris(3,5-dimethylphenylcarbamate)), i-Cellulose-5 (immobilized tris(3,5-dichlorophenylcarbamate)), and i-Amylose-3 (immobilized amylose tris(3-chloro-5-methylphenylcarbamate)) (Phenomenex Inc., Torrance, CA, USA) were used as chiral columns ( $250 \times 4.6 \mathrm{~mm})(5 \mu \mathrm{m})$. i-Cellulose- 5 and i-Amylose- 3 were kindly provided by Prof. Bezhan Chankvetdze, University of Tbilisi (Georgia). HPLC-grade $n$-heptane, $n$-hexane, methanol and 2propanol were purchased and used as received. Analyses were performed at flow rate $0.8 \mathrm{~mL} / \mathrm{min}$ and $22^{\circ} \mathrm{C}$.

General procedures for the Sonogashira reaction.

Cond. A: To the substituted iodoferrocene 1-2 (1 eq.) under argon were successively added degassed diisopropylamine (5mL/mmol), $\mathrm{Pd}\left(\mathrm{PPh}_{3}\right)_{4}$ (5 mol\%) and $\mathrm{CuI} \mathrm{(10} \mathrm{mol \% ).} \mathrm{After}$ stirring at room temperature for $5 \mathrm{~min}$, trimethylsilylacetylene $(3$ eq.) was added and the mixture was heated at $60^{\circ} \mathrm{C}$ and stirred for $15 \mathrm{~h}$. After cooling to room temperature, the mixture was filtered over Celite and washed with dichloromethane. The filtrate was washed with water and the organic phase was collected and dried over $\mathrm{Na}_{2} \mathrm{SO}_{4}$. After filtration and concentration, the crude was purified by chromatography on silica gel (pentane or pentane/Et ${ }_{2} \mathrm{O} 98 / 2$ ) to give the expected product.

Cond. B: To a flask containing iodoferrocene 1-2 (1 eq.), Pd(Pt$\left.\mathrm{Bu}_{3}\right)_{2}$ (3 mol\%) and $\mathrm{CuI}(3 \mathrm{~mol} \%)$ were added a degassed $\mathrm{THF} / i \operatorname{Pr}_{2} \mathrm{NH} \quad 3 / 1$ mixture $(1.5 \mathrm{~mL} / \mathrm{mmol})$ and finally trimethylsilylacetylene (2 eq.). After stirring at room temperature for $20 \mathrm{~h}$, the mixture was filtered over Celite and washed with dichloromethane. After concentration, the crude was purified by chromatography on silica gel (pentane or pentane/Et $\mathrm{E}_{2} \mathrm{O} 98 / 2$ ) to give the expected product.

((2-Bromoferrocenyl)ethynyl)trimethylsilane (4a). Cond. A: 4a (3.04 g, 98\%) obtained from 1a (8.57 mmol, $3.35 \mathrm{~g})$; Cond. $B$ : 4a (115 mg, 89\%) obtained from 1a (0.358 mmol, $140 \mathrm{mg})$. Red solid. Mp: $38-40{ }^{\circ} \mathrm{C} .{ }^{1} \mathrm{H}$ NMR $\left(500 \mathrm{MHz}, \mathrm{CDCl}_{3}\right) \delta 4.47(\mathrm{~s}, 1 \mathrm{H}), 4.41$ $(\mathrm{s}, 1 \mathrm{H}), 4.23(\mathrm{~s}, 5 \mathrm{H}), 4.14(\mathrm{~s}, 1 \mathrm{H}), 0.26(\mathrm{~s}, 9 \mathrm{H}) ;{ }^{13} \mathrm{C} \mathrm{NMR}(126 \mathrm{MHz}$, $\left.\mathrm{CDCl}_{3}\right) \delta 101.7,94.5,81.0,72.9,70.8,70.2,67.3,67.0,0.3$. HRMS (ESI-TOF) $\mathrm{m} / \mathrm{z}$ [M] ${ }^{+}$Calcd for $\mathrm{C}_{15} \mathrm{H}_{17} \mathrm{BrFeSi}$ 359.9627; Found 359.9613.

((2-Chloroferrocenyl)ethynyl)trimethylsilane (4b). Cond. A: 4b (540 mg, 62\%) obtained from 1 b (2.77 mmol, $960 \mathrm{mg}$ ); Cond.
B: $\mathbf{4 b}(82 \mathrm{mg}, 94 \%)$ obtained from $\mathbf{1 b}(0.277 \mathrm{mmol}, 96 \mathrm{mg})$. Red solid. Mp: $45-47{ }^{\circ} \mathrm{C} .{ }^{1} \mathrm{H}$ NMR $\left(500 \mathrm{MHz}, \mathrm{CDCl}_{3}\right) \delta 4.45(\mathrm{~m}, 1 \mathrm{H})$, $4.37(\mathrm{~m}, 1 \mathrm{H}), 4.24(\mathrm{~s}, 5 \mathrm{H}), 4.08(\mathrm{~m}, 1 \mathrm{H}), 0.27(\mathrm{~s}, 9 \mathrm{H}) ;{ }^{13} \mathrm{C}$ NMR $\left(126 \mathrm{MHz} \mathrm{CDCl}_{3}\right) \delta 100.9,94.7,94.5,72.5,69.5,68.4,66.0,65.1$, 0.3. HRMS (ESI-TOF) $\mathrm{m} / \mathrm{z}[\mathrm{M}]+$ Calcd for $\mathrm{C}_{15} \mathrm{H}_{17} \mathrm{ClFeSi} 316.0132$; Found 316.0143.

((2-Fluoroferrocenyl)ethynyl)trimethylsilane (4c). Cond. A: 4c (127 mg, 42\%) obtained from 1c (1 mmol, $330 \mathrm{mg})$; Cond. B: 4c (49 mg, 46\%) obtained from 1c $(0.352 \mathrm{mmol}, 116 \mathrm{mg})$ (50 mg of starting material was recovered). Red oil. ${ }^{1} \mathrm{H}$ NMR (500 $\mathrm{MHz}$, $\left.\mathrm{CDCl}_{3}\right) \delta 4.35(\mathrm{~s}, 1 \mathrm{H}), 4.28(\mathrm{~s}, 5 \mathrm{H}), 4.11(\mathrm{~s}, 1 \mathrm{H}), 3.82(\mathrm{~s}, 1 \mathrm{H}), 0.25$ (s, 9H); ${ }^{13} \mathrm{C} \mathrm{NMR}\left(126 \mathrm{MHz} \mathrm{CDCl}_{3}\right) \delta 135.4(\mathrm{~d}, J=274.9 \mathrm{~Hz}), 99.5$ (d, $J=3.8 \mathrm{~Hz}), 94.4,71.6,65.3(\mathrm{~d}, J=2.5 \mathrm{~Hz}), 60.9(\mathrm{~d}, J=3.8 \mathrm{~Hz})$, $56.5(\mathrm{~d}, J=13.9 \mathrm{~Hz}), 54.6(\mathrm{~d}, J=12.6 \mathrm{~Hz}), 0.3 ;{ }^{19} \mathrm{~F}$ NMR $(75 \mathrm{MHz}$, $\mathrm{CDCl}_{3}$ ) $\delta$-186.7. HRMS (ESI-TOF) $\mathrm{m} / \mathrm{z}[\mathrm{M}]^{+}$Calcd for $\mathrm{C}_{15} \mathrm{H}_{17} \mathrm{FFeSi}$ 300.0427; Found 300.0424.

2-((Trimethylsilyl)ethynyl)cyanoferrocene (4d). Cond. A: 4d was obtained from 1d $(0.816 \mathrm{mmol}, 275 \mathrm{mg})$ as a 3:2 mixture with cyanoferrocene (180 mg); Cond. B: 4d (20 mg, 55\%) obtained from 1d $(0.118 \mathrm{mmol}, 39.6 \mathrm{mg})$. Red oil. ${ }^{1} \mathrm{H}$ NMR $(500 \mathrm{MHz}$, $\left.\mathrm{CDCl}_{3}\right) \delta 4.66(\mathrm{bs}, 1 \mathrm{H}), 4.63(\mathrm{bs}, 1 \mathrm{H}), 4.39(\mathrm{t}, J=2.5 \mathrm{~Hz}, 1 \mathrm{H}), 4.36$ (s, 5H), $0.25(\mathrm{~s}, 9 \mathrm{H}) ;{ }^{13} \mathrm{C}$ NMR $\left(126 \mathrm{MHz} \mathrm{CDCl}_{3}\right) \delta 118.8,99.3,96.2$, 73.8, 72.9, 72.1, 70.8, 69.4, 55.8, 0.2. HRMS (ESI-TOF) m/z [M]+ Calcd for $\mathrm{C}_{16} \mathrm{H}_{17} \mathrm{FeNSi} 307.0474$; Found 307.0455.

((3-Bromoferrocenyl)ethynyl)trimethylsilane (5a). Cond. A: 5a (176 mg, 48\%) obtained from 2a (1.023 mmol, $400 \mathrm{mg})$; Cond. $B$ : 5a (118 mg, 91\%) obtained from 2a (0.358 mmol, $140 \mathrm{mg})$. Red solid. Mp: $58-60{ }^{\circ} \mathrm{C} .{ }^{1} \mathrm{H}$ NMR $\left(500 \mathrm{MHz}, \mathrm{CDCl}_{3}\right) \delta 4.69(\mathrm{~m}, 1 \mathrm{H})$, $4.43(\mathrm{~m}, 1 \mathrm{H}), 4.37(\mathrm{~m}, 1 \mathrm{H}), 4.26(\mathrm{~s}, 5 \mathrm{H}), 0.21(\mathrm{~s}, 9 \mathrm{H}) ;{ }^{13} \mathrm{C}$ NMR $\left(126 \mathrm{MHz} \mathrm{CDCl}_{3}\right) \delta 102.5,92.1,77.2,73.5,72.8,71.0,70.8,64.6$, 0.3. HRMS (ESI-TOF) $\mathrm{m} / \mathrm{z}[\mathrm{M}]^{+}$Calcd for $\mathrm{C}_{15} \mathrm{H}_{17} \mathrm{BrFeSi} 359.9627$; Found 359.9619.

((3-Chloroferrocenyl)ethynyl)trimethylsilane (5b). Cond. A: $\mathbf{5 b}$ (55 mg, 38\%) obtained from $\mathbf{2 b}$ (0.462 mmol, $160 \mathrm{mg})$; Cond. $B$ : $\mathbf{5 b}$ (134 mg, 92\%) obtained from $2 \mathbf{b}(0.462 \mathrm{mmol}, 160 \mathrm{mg})$. Red oil. ${ }^{1} \mathrm{H}$ NMR (500 MHz, $\left.\mathrm{CDCl}_{3}\right) \delta 4.67(\mathrm{~s}, 1 \mathrm{H}), 4.40(\mathrm{~m}, 1 \mathrm{H})$, $4.33(\mathrm{~s}, 1 \mathrm{H}), 4.27(\mathrm{~s}, 5 \mathrm{H}), 0.21(\mathrm{~s}, 9 \mathrm{H}) ;{ }^{13} \mathrm{C} \mathrm{NMR}\left(126 \mathrm{MHz}^{\left.-\mathrm{CDCl}_{3}\right)} \delta\right.$ 102.6, 92.2, 91.8, 72.5, 71.3, 69.8, 68.7, 63.5, 0.3. HRMS (ESI-TOF) $\mathrm{m} / \mathrm{z}[\mathrm{M}]^{+}$Calcd for $\mathrm{C}_{15} \mathrm{H}_{17} \mathrm{ClFeSi}$ 316.0132; Found 316.0140.

((3-Fluoroferrocenyl)ethynyl)trimethylsilane (5c). Cond. A: 5c (46 mg, 31\%) obtained from 2c $(0.5 \mathrm{mmol}, 165 \mathrm{mg})$; Cond. B: $\mathbf{5 c}$ (111 mg, 74\%) obtained from $2 \mathrm{c}(0.5 \mathrm{mmol}, 165 \mathrm{mg})$. Red oil. ${ }^{1} \mathrm{H}$ NMR (500 MHz, $\left.\mathrm{CDCl}_{3}\right) \delta 4.60(\mathrm{~s}, 1 \mathrm{H}), 4.34(\mathrm{~s}, 1 \mathrm{H}), 4.30(\mathrm{~s}, 5 \mathrm{H})$, $4.11(\mathrm{~s}, 1 \mathrm{H}), 0.21(\mathrm{~s}, 9 \mathrm{H}) ;{ }^{13} \mathrm{C} \mathrm{NMR}\left(126 \mathrm{MHz}, \mathrm{CDCl}_{3}\right) \delta 134.6(\mathrm{~d}, J=$ $270.9 \mathrm{~Hz}), 103.2,91.1,71.7,65.0,59.6$ (d, $J=15.1 \mathrm{~Hz}), 58.5(\mathrm{~d}, J=$ $5.0 \mathrm{~Hz}), 57.0(\mathrm{~d}, J=15.1 \mathrm{~Hz}), 0.3 ;{ }^{19} \mathrm{~F}$ NMR $\left(75 \mathrm{MHz}, \mathrm{CDCl}_{3}\right) \delta-$ 186.1. HRMS (ESI-TOF) $\mathrm{m} / \mathrm{z}[\mathrm{M}]+{ }^{+}$Calcd for $\mathrm{C}_{15} \mathrm{H}_{17} \mathrm{FFeSi} 300.0427$; Found 300.0435.

General procedure for aldehyde homologation. Ferrocene carboxaldehyde $\left(S_{\mathrm{Fc}}\right)$-36 or $\left(S_{\mathrm{Fc}}\right)-39$ (1 eq.) was dissolved in THF ( $3 \mathrm{~mL} / \mathrm{mmol}$ ) and the temperature was lowered to $0^{\circ} \mathrm{C}$. A solution of diazophosphonate 38 (1.2 eq) in $\mathrm{MeOH}(2.5 \mathrm{~mL} / \mathrm{mmol})$ was added followed by $\mathrm{K}_{2} \mathrm{CO}_{3}$ (2.2 eq.). The temperature was raised to room temperature and the mixture was stirred for $15 \mathrm{~h}$. After concentration, the crude was extracted with $\mathrm{Et}_{2} \mathrm{O}$, washed with water and brine. The organic phases were collected, dried over $\mathrm{Na}_{2} \mathrm{SO}_{4}$ and concentrated. The crude was purified by chromatography on silica gel (pentane/Et $\mathrm{O}_{2} \mathrm{4/1}$ ) to give the expected product.

$\left(S_{\mathrm{Fc}}\right)$-1-Bromo-2-ethynylferrocene $\left(\left(\boldsymbol{S}_{\mathrm{Fc}}\right)-37\right)$. Red oil $(1.59 \mathrm{~g}$, $89 \%)$ obtained from $\left(S_{\mathrm{Fc}}\right)-36(6.14 \mathrm{mmol}, 1.8 \mathrm{~g}) .{ }^{1} \mathrm{H}$ NMR $(500$ $\mathrm{MHz}^{\mathrm{CDCl}} 3$ ) $\delta 4.50(\mathrm{bs}, 1 \mathrm{H}), 4.45(\mathrm{bs}, 1 \mathrm{H}), 4.26(\mathrm{~s}, 5 \mathrm{H}), 4.17(\mathrm{t}, J=$ $2.5 \mathrm{~Hz}, 1 \mathrm{H}), 2.94(\mathrm{~s}, 1 \mathrm{H}) ;{ }^{13} \mathrm{C}$ NMR $\left(126 \mathrm{MHz}, \mathrm{CDCl}_{3}\right) \delta 80.8,80.5$, 76.8, 72.8, 70.9, 70.5, 67.4, 66.0. $[\alpha]_{\mathrm{D}^{20}}=+21\left(\mathrm{c}=0.7, \mathrm{CHCl}_{3}\right)$. HRMS (ESI-TOF) m/z [M] ${ }^{+}$Calcd for $\mathrm{C}_{12} \mathrm{H}_{9} \mathrm{BrFe} 287.9232$; Found 287.9228.

$\left(\boldsymbol{S}_{\mathrm{Fc}}\right)$-1-Ethynyl-3-iodoferrocene $\left(\left(\boldsymbol{S}_{\mathrm{Fc}}\right)-40\right)$. Red oil $(460 \mathrm{mg}$, $86 \%)$ obtained from $\left(S_{\mathrm{Fc}}\right)-39$ (1.59 mmol, $\left.540 \mathrm{mg}\right) .{ }^{1} \mathrm{H}$ NMR $(500$ $\mathrm{MHz}_{\mathrm{CDCl}}$ ) $\delta 4.72$ (bs, 1H), 4.453 (s, 1H), 4.451 (s, 1H), 4.25 (s, 
5H), $2.77(\mathrm{~s}, 1 \mathrm{H}) ;{ }^{13} \mathrm{C}$ NMR (126 MHz, $\left.\mathrm{CDCl}_{3}\right) \delta 81.0,77.8,75.4$, $75.1,73.1,72.6,65.3,38.9 .[\alpha]_{\mathrm{D}}{ }^{20}=+125\left(\mathrm{c}=0.5, \mathrm{CHCl}_{3}\right)$. HRMS (ESI-TOF) $\mathrm{m} / \mathrm{z}$ [M] ${ }^{+}$Calcd for $\mathrm{C}_{12} \mathrm{H}_{9} \mathrm{FeI}$ 335.9093; Found 335.9083.

General procedure for TMS protection. To a solution of ethynylferrocene $\left(S_{\mathrm{Fc}}\right)-\mathbf{3 7}$ or $\left(S_{\mathrm{Fc}}\right)-\mathbf{4 0}(1$ eq. $)$ at $-78^{\circ} \mathrm{C}$ was added a freshly prepared solution of LiHMDS (1M in THF, 1.5 eq.) and the mixture was stirred for $30 \mathrm{~min}$ at $-78^{\circ} \mathrm{C}$. TMSCl (1.5 eq.) was added and stirring was continued $30 \mathrm{~min}$ at $-78^{\circ} \mathrm{C}$ before raising the temperature to ambient. A saturated solution of $\mathrm{NH}_{4} \mathrm{Cl}$ was added and the mixture was extracted with $\mathrm{Et}_{2} \mathrm{O}$ and washed with water. After drying the organic phase over $\mathrm{Na}_{2} \mathrm{SO}_{4}$, it was filtered and concentrated. The crude was purified by chromatography on silica gel (pentane/ $\mathrm{Et}_{2} \mathrm{O}$ 8/1) to give the expected product.

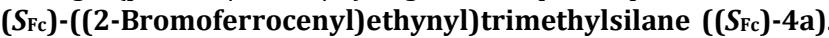
Red oil (1.75 g, 99\%) obtained from $\left(S_{\mathrm{Fc}}\right)-37$ (4.84 mmol, $\left.1.4 \mathrm{~g}\right)$. $[\alpha]_{\mathrm{D}^{20}}=-16\left(\mathrm{c}=0.7, \mathrm{CHCl}_{3}\right)$. HRMS (ESI-TOF) $\mathrm{m} / \mathrm{z}[\mathrm{M}]^{+}$Calcd for $\mathrm{C}_{15} \mathrm{H}_{17} \mathrm{BrFeSi} 359.9627$; Found 359.9637.

$\left(\left(S_{\mathrm{Fc}}\right)-\left(\left(3-\right.\right.\right.$ Iodoferrocenyl)ethynyl)trimethylsilane $\quad\left(\left(S_{\mathrm{Fc}}\right)-41\right)$ Red solid (540 mg, 99\%) obtained from $\left(S_{\mathrm{FC}}\right)-40$ (1.335 mmol, $450 \mathrm{mg}$ ). Mp: $50-52^{\circ} \mathrm{C} .{ }^{1} \mathrm{H}$ NMR $\left(500 \mathrm{MHz}, \mathrm{CDCl}_{3}\right) \delta 4.69(\mathrm{~s}, 1 \mathrm{H})$, $4.43(\mathrm{~s}, 1 \mathrm{H}), 4.41(\mathrm{~s}, 1 \mathrm{H}), 4.22(\mathrm{~s}, 5 \mathrm{H}), 0.22(\mathrm{~s}, 9 \mathrm{H}) ;{ }^{13} \mathrm{C}$ NMR $(126$ $\left.\mathrm{MHz}, \mathrm{CDCl}_{3}\right) \delta 102.4,92.3,77.8,75.3,73.2,72.5,66.3,39.1,0.3$. $[\alpha]_{\mathrm{D}}{ }^{20}=+126\left(\mathrm{c}=0.6, \mathrm{CHCl}_{3}\right)$. HRMS (ESI-TOF) $\mathrm{m} / \mathrm{z}[\mathrm{M}]^{+}$Calcd for $\mathrm{C}_{15} \mathrm{H}_{17} \mathrm{FeISi}$ 407.9488; Found 407.9486.

General procedure for the Suzuki reaction. Haloferrocene 4a, 5a or $\left(S_{\mathrm{Fc}}\right)-41$ (1 eq.), $\mathrm{Pd}_{2} \mathrm{dba}_{3}(2 \mathrm{~mol} \%)$, SPhos ( $4 \mathrm{~mol} \%$ ), boronic acid (1.5 eq.) and crushed $\mathrm{K}_{3} \mathrm{PO}_{4}$ (3 eq.) were placed in a Schlenk tube under argon. Degassed toluene ( $3 \mathrm{ml} / \mathrm{mmol})$ was added and the mixture was heated at $100^{\circ} \mathrm{C}$ and stirred for $15 \mathrm{~h}$. After cooling to room temperature, the mixture was filtered over Celite and washed with ethylacetate. The filtrate was concentrated and purified by chromatography on silica gel (pentane or pentane/Et ${ }_{2} \mathrm{O} 98 / 2$ ) to give the expected product.

Trimethyl((2-phenylferrocenyl)ethynyl)silane (6a). Red solid (1.05 g, 98\%) obtained from 4a (3 mmol, $1.08 \mathrm{~g}) . \mathrm{Mp}: 46-48^{\circ} \mathrm{C} .{ }^{1} \mathrm{H}$ NMR $\left(500 \mathrm{MHz}, \mathrm{CDCl}_{3}\right) \delta 7.87(\mathrm{~d}, J=7.0 \mathrm{~Hz}, 2 \mathrm{H}), 7.35(\mathrm{t}, J=7.0 \mathrm{~Hz}$, $2 \mathrm{H}), 7.27(\mathrm{t}, J=7.0 \mathrm{~Hz}, 1 \mathrm{H}), 4.63(\mathrm{~m}, 1 \mathrm{H}), 4.61(\mathrm{~m}, 1 \mathrm{H}), 4.33(\mathrm{t}, \mathrm{J}=$ $3.0 \mathrm{~Hz}, 1 \mathrm{H}), 4.13(\mathrm{~s}, 5 \mathrm{H}), 0.27(\mathrm{~s}, 9 \mathrm{H}) ;{ }^{13} \mathrm{C} \mathrm{NMR}\left(126 \mathrm{MHz}^{\mathrm{CDCl}} 3\right) \delta$ 138.0, 128.0, 127.9, 126.6, 104.7, 93.8, 87.9, 73.0, 71.9, 68.6, 68.5, 63.9, 0.2. HRMS (ESI-TOF) $\mathrm{m} / \mathrm{z}[\mathrm{M}]^{+}$Calcd for $\mathrm{C}_{21} \mathrm{H}_{22} \mathrm{FeSi}$ 358.0835; Found 358.0823.

$\left(S_{\mathrm{Fc}}\right)$-Trimethyl((2-phenylferrocenyl)ethynyl)silane $\quad\left(\left(S_{\mathrm{Fc}}\right)-\right.$ 6a). Red oil ( $160 \mathrm{mg}, 89 \%)$ obtained from $\left(S_{\mathrm{Fc}}\right)-4 a(0.5 \mathrm{mmol}, 180$ $\mathrm{mg}) \cdot[\alpha]_{\mathrm{D}}{ }^{20}=-16\left(\mathrm{c}=0.5, \mathrm{CHCl}_{3}\right)$. HRMS (ESI-TOF) $\mathrm{m} / \mathrm{z}[\mathrm{M}]^{+}$Calcd for $\mathrm{C}_{21} \mathrm{H}_{22} \mathrm{FeSi}$ 358.0835; Found 358.0829.

Trimethyl((2-(naphthalen-2-yl)ferrocenyl)ethynyl)silane (6b). Red oil (572 mg, 93\%) obtained from 4a (1.5 mmol, 542 mg). ${ }^{1} \mathrm{H}$ NMR (500 MHz, $\left.\mathrm{CDCl}_{3}\right) \delta 8.33(\mathrm{~s}, 1 \mathrm{H}), 8.00(\mathrm{dd}, J=8.5,1.5$ $\mathrm{Hz}, 1 \mathrm{H}), 7.83(\mathrm{~m}, 3 \mathrm{H}), 7.47(\mathrm{~m}, 2 \mathrm{H}), 4.74(\mathrm{~m}, 1 \mathrm{H}), 4.65(\mathrm{~m}, 1 \mathrm{H})$, $4.38(\mathrm{t}, J=3.0 \mathrm{~Hz}, 1 \mathrm{H}), 4.13(\mathrm{~s}, 5 \mathrm{H}), 0.29(\mathrm{~s}, 9 \mathrm{H}) ;{ }^{13} \mathrm{C}$ NMR $(126$ $\left.\mathrm{MHz}, \mathrm{CDCl}_{3}\right) \delta 135.6,133.5,132.4,127.85,127.8,127.4,126.7$, 126.3, 125.8, 125.6, 104.7, 93.9, 87.5, 73.4, 71.9, 68.85, 68.8, 63.9, 0.3. HRMS (ESI-TOF) $\mathrm{m} / \mathrm{z}[\mathrm{M}]^{+}$Calcd for $\mathrm{C}_{25} \mathrm{H}_{24} \mathrm{FeSi}$ 408.0991; Found 408.0997.

$\left(S_{\mathrm{Fc}}\right)$-Trimethyl((2-(naphthalen-2-

yl)ferrocenyl)ethynyl)silane $\left(\left(\boldsymbol{S}_{\mathrm{Fc}}\right)-6 \mathbf{b}\right)$. Red oil $(200 \mathrm{mg}, 98 \%)$ obtained from $\left(S_{\mathrm{Fc}}\right)-\mathbf{4 a}(0.5 \mathrm{mmol}, 180 \mathrm{mg}) .[\alpha]_{\mathrm{D}}^{20}=+107(\mathrm{c}=0.5$, $\mathrm{CHCl}_{3}$ ). HRMS (ESI-TOF) m/z [M] ${ }^{+}$Calcd for $\mathrm{C}_{25} \mathrm{H}_{24} \mathrm{FeSi} 408.0991$; Found 408.0971.

Trimethyl((3-phenylferrocenyl)ethynyl)silane (7a). Red solid (60 mg, 82\%) obtained from 5a $(0.208 \mathrm{mmol}, 75 \mathrm{mg})$. Mp: $120-$ $122^{\circ} \mathrm{C} .{ }^{1} \mathrm{H}$ NMR $\left(500 \mathrm{MHz}, \mathrm{CDCl}_{3}\right) \delta 7.45(\mathrm{~d}, J=7.0 \mathrm{~Hz}, 2 \mathrm{H}), 7.30(\mathrm{t}$, $J=7.0 \mathrm{~Hz}, 2 \mathrm{H}), 7.21(\mathrm{t}, J=7.0 \mathrm{~Hz}, 1 \mathrm{H}), 4.93(\mathrm{~m}, 1 \mathrm{H}), 4.66(\mathrm{~m}, 1 \mathrm{H})$, $4.58(\mathrm{~m}, 1 \mathrm{H}), 4.09(\mathrm{~s}, 5 \mathrm{H}), 0.25(\mathrm{~s}, 9 \mathrm{H}) ;{ }^{13} \mathrm{C} \mathrm{NMR}\left(126 \mathrm{MHz}, \mathrm{CDCl}_{3}\right)$ $\delta$ 138.3, 128.6, 126.5, 126.3, 104.0, 91.2, 86.3, 72.6, 71.8, 70.1, 67.3, 65.8, 0.4. HRMS (ESI-TOF) $\mathrm{m} / \mathrm{z}[\mathrm{M}]^{+}$Calcd for Calcd for $\mathrm{C}_{21} \mathrm{H}_{22} \mathrm{FeSi}$ 358.0835; Found 358.0843.
$\left(S_{\mathrm{Fc}}\right)$-Trimethyl((3-phenylferrocenyl)ethynyl)silane $\quad\left(\left(S_{\mathrm{Fc}}\right)-\right.$ 7a). Red solid (130 mg, 84\%) obtained from $\left(S_{\mathrm{Fc}}\right)-41(0.43 \mathrm{mmol}$, $175 \mathrm{mg}$ ). Mp: $142-144^{\circ} \mathrm{C} .[\alpha]_{\mathrm{D}}{ }^{20}=+65\left(\mathrm{c}=0.5, \mathrm{CHCl}_{3}\right)$. HRMS (ESITOF) $\mathrm{m} / \mathrm{z}$ [M] ${ }^{+}$Calcd for $\mathrm{C}_{21} \mathrm{H}_{22} \mathrm{FeSi} 358.0835$; Found 358.0837. Trimethyl((3-(naphthalen-2-yl)ferrocenyl)ethynyl)silane (7b). Red solid (46 mg, 80\%) obtained from 5 a $(0.141 \mathrm{mmol}, 51$ mg). Mp: $85-87^{\circ} \mathrm{C} .{ }^{1} \mathrm{H}$ NMR $\left(500 \mathrm{MHz}, \mathrm{CDCl}_{3}\right) \delta 7.86(\mathrm{~s}, 1 \mathrm{H}), 7.79$ $(\mathrm{m}, 3 \mathrm{H}), 7.61$ (dd, $J=8.5,1.5 \mathrm{~Hz}, 1 \mathrm{H}), 7.46(\mathrm{~m}, 2 \mathrm{H}), 5.07(\mathrm{~m}, 1 \mathrm{H})$, $4.79(\mathrm{~m}, 1 \mathrm{H}), 4.65(\mathrm{t}, J=3.0 \mathrm{~Hz}, 1 \mathrm{H}), 4.10(\mathrm{~s}, 5 \mathrm{H}), 0.26(\mathrm{~s}, 9 \mathrm{H}) ;{ }^{13} \mathrm{C}$ NMR $\left(126 \mathrm{MHz}, \mathrm{CDCl}_{3}\right) \delta 135.8,133.7,132.4,128.1,127.9,127.7$, 126.5, 125.6, 125.2, 124.0, 103.9, 91.3, 86.1, 72.8, 71.9, 70.3, 67.4, 66.1, 0.4. HRMS (ESI-TOF) $\mathrm{m} / \mathrm{z}$ [M] ${ }^{+}$Calcd for $\mathrm{C}_{25} \mathrm{H}_{24} \mathrm{FeSi}$ 408.0991; Found 408.0994.

$\left(S_{\mathrm{Fc}}\right)$-Trimethyl((3-(naphthalen-2-

yl)ferrocenyl)ethynyl)silane $\left(\left(S_{\mathrm{Fc}}\right)-7 \mathbf{b}\right)$. Red solid $(150 \mathrm{mg}$, $85 \%)$ obtained from $\left(S_{\mathrm{Fc}}\right)-\mathbf{4 1}(0.43 \mathrm{mmol}, 175 \mathrm{mg})$. Mp: $95-97^{\circ} \mathrm{C}$. $[\alpha]_{\mathrm{D}^{20}}=+131\left(\mathrm{c}=0.7, \mathrm{CHCl}_{3}\right)$. HRMS (ESI-TOF) $\mathrm{m} / \mathrm{z}[\mathrm{M}]^{+}$Calcd for $\mathrm{C}_{25} \mathrm{H}_{24} \mathrm{FeSi}$ 408.0991; Found 408.0991.

General procedure for the lithiation/electrophilic trapping. To a solution of $\mathbf{4 a}$ or $\left(S_{\mathrm{Fc}}\right)-\mathbf{4 a}(1 \mathrm{eq})$ in THF $(5 \mathrm{~mL} / \mathrm{mmol})$ at $78^{\circ} \mathrm{C}$ was slowly added $n$-BuLi $(1.4 \mathrm{M}$ in hexanes, 1.2 eq.) and the mixture was stirred at $-78^{\circ} \mathrm{C}$ for $1 \mathrm{~h}$. Electrophile $(1.2$ eq.) was added and stirring was continued at $-78^{\circ} \mathrm{C}$ for $1 \mathrm{~h}$. The temperature was raised to $0^{\circ} \mathrm{C}$ before quenching with a saturated solution of $\mathrm{NH}_{4} \mathrm{Cl}$. The mixture was extracted with ethyl acetate, washed with water and brine. After drying over $\mathrm{Na}_{2} \mathrm{SO}_{4}$, filtration and concentration, the crude was purified by chromatography on silica gel (pentane/Et 20 98/2) to give the expected product.

Trimethyl((2-methylferrocenyl)ethynyl)silane (8). Red oil (208 mg, 70\%) obtained by using $1 \mathrm{mmol}$ of $\mathbf{4 a}$ and $1.2 \mathrm{mmol}$ of MeI (neat) as the electrophile. ${ }^{1} \mathrm{H}$ NMR $\left(500 \mathrm{MHz}, \mathrm{CDCl}_{3}\right) \delta 4.34$ $(\mathrm{m}, 1 \mathrm{H}), 4.14(\mathrm{~m}, 1 \mathrm{H}), 4.09(\mathrm{~s}, 5 \mathrm{H}), 4.04(\mathrm{t}, J=2.5 \mathrm{~Hz}, 1 \mathrm{H}), 2.08(\mathrm{~s}$, $3 \mathrm{H}), 0.24(\mathrm{~s}, 9 \mathrm{H}) ;{ }^{13} \mathrm{C} \mathrm{NMR}\left(126 \mathrm{MHz}, \mathrm{CDCl}_{3}\right) \delta 104.0,92.5,87.0$, $70.9,70.6,69.7,67.1,65.8,13.7,0.5$. HRMS (ESI-TOF) $\mathrm{m} / \mathrm{z}[\mathrm{M}]^{+}$ Calcd for $\mathrm{C}_{16} \mathrm{H}_{20} \mathrm{FeSi}$ 296.0678; Found 296.0671.

$\left(R_{\mathrm{Fc}}\right)$-Trimethyl((2-methylferrocenyl)ethynyl)silane $\left(\left(R_{\mathrm{Fc}}\right)-8\right)$. Red solid (120 mg, 73\%) obtained by using by using $0.55 \mathrm{mmol}$ of 4a and $0.66 \mathrm{mmol}$ of $\mathrm{MeI}$ (neat) as the electrophile. Mp: $33-35^{\circ} \mathrm{C}$. $[\alpha]_{\mathrm{D}^{20}}=-49\left(\mathrm{c}=0.3, \mathrm{CHCl}_{3}\right)$. HRMS (ESI-TOF) $\mathrm{m} / \mathrm{z}[\mathrm{M}]^{+}$Calcd for $\mathrm{C}_{16} \mathrm{H}_{20} \mathrm{FeSi}$ 296.0678; Found 296.0662.

$\left(S_{\mathrm{Fc}}\right)-\left(\left(2-\right.\right.$ Fluoroferrocenyl)ethynyl)trimethylsilane $\left(\left(S_{\mathrm{Fc}}\right)-4 \mathrm{c}\right)$. Red oil (118 mg, 71\%) obtained by using $0.55 \mathrm{mmol}$ of $\mathbf{4 a}$ and $0.66 \mathrm{mmol}$ of NFSI (solid) as the electrophile. $[\alpha]_{\mathrm{D}}{ }^{20}=-4(\mathrm{c}=1.4$, $\mathrm{CHCl}_{3}$ ). HRMS (ESI-TOF) $\mathrm{m} / \mathrm{z} \quad[\mathrm{M}]^{+}$Calcd for $\mathrm{C}_{15} \mathrm{H}_{17} \mathrm{FFeSi}$ 300.0427; Found 300.0431.

$\left(S_{\mathrm{Fc}}\right)-2-((T r i m e t h y l s i l y l) e t h y n y l) c y a n o f e r r o c e n e \quad\left(\left(S_{\mathrm{Fc}}\right)-4 \mathrm{~d}\right)$. Red oil $(70 \mathrm{mg}, 41 \%)$ obtained by using $0.55 \mathrm{mmol}$ of $4 \mathrm{a}$ and 0.66 mmol of TsCN (in THF) as the electrophile. $[\alpha]_{D^{20}}=-37$ (c $=0.2$, $\mathrm{CHCl}_{3}$ ). HRMS (ESI-TOF) $\mathrm{m} / \mathrm{z}[\mathrm{M}]^{+}$Calcd for $\mathrm{C}_{16} \mathrm{H}_{17} \mathrm{FeNSi}$ 307.0474; Found 307.0465.

$\left(S_{\mathrm{Fc}}\right)$-((3-Bromoferrocenyl)ethynyl)trimethylsilane $\left(\left(S_{\mathrm{Fc}}\right)-5 \mathrm{a}\right)$. $\left(S_{\mathrm{Fc}}\right)$-41 (0.452 mmol, $\left.185 \mathrm{mg}\right)$ was dissolved in THF (3 mL) and the solution was cooled to $-78^{\circ} \mathrm{C}$. $t$-BuLi $(1.7 \mathrm{M}$ in pentane, 0.95 mmol, $0.56 \mathrm{~mL}$ ) was slowly added and the mixture was stirred at $78^{\circ} \mathrm{C}$ for $30 \mathrm{~min}$. A solution of $\alpha, \alpha^{\prime}$-dibromoxylene $(0.54 \mathrm{mmol}$, $140 \mathrm{mg}$ ) in THF ( $2 \mathrm{~mL}$ ) was added and stirring was continued for $30 \mathrm{~min}$. The temperature was raised to ambient and water $(0.5$ $\mathrm{mL}$ ) was slowly added. After filtration on Celite $\left(\mathrm{Et}_{2} \mathrm{O}\right)$, the organic phase was separated and dried over $\mathrm{Na}_{2} \mathrm{SO}_{4}$. After filtration and concentration, the crude was purified by chromatography on silica gel (pentane) to give a red solid (150 mg) with similar ${ }^{1} \mathrm{H}$ NMR spectrum than racemic 5a. However, it contained some inseparable impurities, and was used without further purification in the next step.

General procedures for the deprotection-iodination.

Cond. a: The ferrocenyl ethynyltrimethylsilane (1 eq.) was dissolved in acetonitrile $(10 \mathrm{~mL} / \mathrm{mmol})$ and placed in the dark at room temperature. AgF (1.1 eq.) and NIS (1.1 eq.) were successively added and the mixture was stirred for $15 \mathrm{~h}$. After filtration 
over Celite $\left(\mathrm{Et}_{2} \mathrm{O}\right)$ and concentration, the crude was purified by chromatography on silica gel (pentane or pentane/Et ${ }_{2} \mathrm{O} 98 / 2$ ) to give the expected product.

Cond. $b$ : The ferrocenyl ethynyltrimethylsilane (1 eq.) was dissolved in methanol $(15 \mathrm{~mL} / \mathrm{mmol})$ and the solution was cooled to $0^{\circ} \mathrm{C}$. Crushed $\mathrm{KOH}$ (2.5 eq.) was added and the mixture was stirred at $0^{\circ} \mathrm{C}$ for $5 \mathrm{~min}$ and at room temperature for $2 \mathrm{~h}$. Diethyl ether was added and the mixture was washed water, then with brine. The organic phase was extracted, dried over $\mathrm{Na}_{2} \mathrm{SO}_{4}$, filtered and concentrated. The crude was purified by chromatography on silica gel (pentane/Et ${ }_{2} \mathrm{O} 99 / 1$ ) to give the free alkynes. 1-Chloro-2-ethynylferrocene (14). Compound 14 (red oil, 25 $\mathrm{mg}, 79 \%)$ obtained from $\mathbf{4 b}(0.13 \mathrm{mmol}, 41 \mathrm{mg})$ and $\mathrm{KOH}(0.325$ mmol, $18.2 \mathrm{mg}$ ) in $\mathrm{MeOH}(2 \mathrm{~mL}) .{ }^{1} \mathrm{H}$ NMR (500 MHz, $\left.\mathrm{CDCl}_{3}\right) \delta 4.47$ (br s, 1H), 4.40 (br s, 1H), $4.27(\mathrm{~s}, 5 \mathrm{H}), 4.11$ (t, J = 2.5 Hz, 1H), 2.95 (s, 1H); ${ }^{13} \mathrm{C}$ NMR (126 MHz, $\left.\mathrm{CDCl}_{3}\right) \delta 94.5,79.7,72.5,69.7,68.5$, 66.1, 64.1. HRMS (ESI-TOF) $\mathrm{m} / \mathrm{z}$ [M] ${ }^{+}$Calcd for $\mathrm{C}_{12} \mathrm{H}_{9} \mathrm{ClFe}$ 243.9737; Found 243.9750.

1-Chloro-3-ethynylferrocene (15). Compound 15 (red oil, 46 $\mathrm{mg}, 87 \%)$ obtained from compound $\mathbf{5 b}(0.212 \mathrm{mmol}, 67 \mathrm{mg})$ and $\mathrm{KOH}(0.529 \mathrm{mmol}, 29.6 \mathrm{mg})$ in $\mathrm{MeOH}(3.2 \mathrm{~mL}) .{ }^{1} \mathrm{H} \mathrm{NMR}(500 \mathrm{MHz}$, $\left.\mathrm{CDCl}_{3}\right) \delta 4.69(\mathrm{br} \mathrm{s}, 1 \mathrm{H}), 4.43($ br s, $1 \mathrm{H}), 4.36$ (br s, $\left.1 \mathrm{H}\right), 4.29(\mathrm{~s}$, $5 \mathrm{H}), 2.71(\mathrm{~s}, 1 \mathrm{H}) ;{ }^{13} \mathrm{C}$ NMR $\left(126 \mathrm{MHz}, \mathrm{CDCl}_{3}\right) \delta 92.2,81.3,74.6$, 72.4, 71.3, 69.8, 68.7. HRMS (ESI-TOF) $\mathrm{m} / \mathrm{z}[\mathrm{M}]^{+}$Calcd for $\mathrm{C}_{12} \mathrm{H}_{9} \mathrm{ClFe} 243.9737$; Found 243.9756.

Cond. $c$ : The free alkynylferrocene (1 eq.) was dissolved in methanol $(15 \mathrm{~mL} / \mathrm{mmol})$ and the solution was cooled to $0^{\circ} \mathrm{C}$. Crushed $\mathrm{KOH}$ ( 2.5 eq.) was added and the mixture was stirred at $0^{\circ} \mathrm{C}$ for 15 min. NIS (1.5 eq.) was added and the mixture was stirred for 5 min at $0^{\circ} \mathrm{C}$ then $2 \mathrm{~h}$ at room temperature. Diethyl ether was added and the mixture was washed water, then with brine. The organic phase was extracted, dried over $\mathrm{Na}_{2} \mathrm{SO}_{4}$, filtered and concentrated. The crude was purified by chromatography on silica gel (pentane/Et ${ }_{2} \mathrm{O} 99 / 1$ ) to give the iodoalkynes.

Cond. $d$ (one pot): The ferrocenyl ethynyltrimethylsilane (1 eq.) was dissolved in methanol $(15 \mathrm{~mL} / \mathrm{mmol})$ and the solution was cooled to $0^{\circ} \mathrm{C}$. Crushed $\mathrm{KOH}$ ( 5 eq.) was added and the mixture was stirred at $0^{\circ} \mathrm{C}$ for $5 \mathrm{~min}$ and at room temperature for $2 \mathrm{~h}$. After cooling to $0^{\circ} \mathrm{C}$, NIS (1.5 eq.) was added and the mixture was stirred for $5 \mathrm{~min}$ at $0^{\circ} \mathrm{C}$ then $2 \mathrm{~h}$ at room temperature. Diethyl ether was added and the mixture was washed water, then with brine. The organic phase was extracted, dried over $\mathrm{Na}_{2} \mathrm{SO}_{4}$, filtered and concentrated. The crude was purified by chromatography on silica gel (pentane/Et 20 99/1) to give the iodoalkynes.

1-Bromo-2-(iodoethynyl)ferrocene (9a). Cond. a: 9a (82 mg, $56 \%$ ) obtained from 4a (0.354 mmol, $128 \mathrm{mg}$ ); Cond. $d$ : 9a (49 $\mathrm{mg}, 71 \%)$ obtained from $4 a(0.166 \mathrm{mmol}, 60 \mathrm{mg})$. Red solid. Mp: 70-72 ${ }^{\circ} \mathrm{C} .{ }^{1} \mathrm{H}$ NMR $\left(500 \mathrm{MHz}, \mathrm{CDCl}_{3}\right) \delta 4.48(\mathrm{~m}, 1 \mathrm{H}), 4.43(\mathrm{~m}, 1 \mathrm{H})$, $4.27(\mathrm{~s}, 5 \mathrm{H}), 4.15(\mathrm{t}, J=2.5 \mathrm{~Hz}, 1 \mathrm{H}) ;{ }^{13} \mathrm{C}$ NMR $\left(126 \mathrm{MHz}, \mathrm{CDCl}_{3}\right) \delta$ 89.9, 80.9, 72.7, 70.7, 70.5, 67.7, 67.3, 3.5. HRMS (ESI-TOF) $\mathrm{m} / \mathrm{z}$ $[\mathrm{M}]+{ }^{+}$Calcd for $\mathrm{C}_{12} \mathrm{H}_{8} \mathrm{BrFeI}$ 413.8198; Found 413.8202 .

$\left(S_{\mathrm{Fc}}\right)-1-B r o m o-2-(i o d o e t h y n y l)$ ferrocene $\left(\left(S_{\mathrm{Fc}}\right)-9 \mathrm{a}\right)$. Cond. a: $(61 \mathrm{mg}, 53 \%)$ obtained from $\left(S_{\mathrm{Fc}}\right)-4 a(0.277 \mathrm{mmol}, 100 \mathrm{mg})$; Cond. $d$ : 9a (36 mg, 87\%) obtained from $\left(S_{\mathrm{Fc}}\right)-4 a(0.1 \mathrm{mmol}, 36$ mg). Red solid. Mp: $99-101{ }^{\circ} \mathrm{C} .[\alpha]_{\mathrm{D}}{ }^{20}=+12\left(\mathrm{c}=0.6, \mathrm{CHCl}_{3}\right)$. HRMS (ESI-TOF) $\mathrm{m} / \mathrm{z}$ [M] ${ }^{+}$Calcd for $\mathrm{C}_{12} \mathrm{H}_{8}$ BrFeli 413.8198; Found 413.8102.

1-Chloro-2-(iodoethynyl)ferrocene (9b). Cond. $a$ : $9 \mathbf{b}$ (124 mg, 48\%) obtained from 4b (0.695 mmol, $220 \mathrm{mg})$; Cond. c: $9 \mathbf{b}(25$ $\mathrm{mg}, 72 \%)$ obtained from 14 (0.094 mmol, $23 \mathrm{mg})$; Cond. $d$ : $9 \mathbf{b}$ (37 $\mathrm{mg}, 77 \%)$ obtained from $\mathbf{4 b}(0.13 \mathrm{mmol}, 41 \mathrm{mg})$. Red solid. Mp: $80-82^{\circ} \mathrm{C} .{ }^{1} \mathrm{H}$ NMR $\left(500 \mathrm{MHz}, \mathrm{CDCl}_{3}\right) \delta 4.45(\mathrm{~m}, 1 \mathrm{H}), 4.38(\mathrm{~m}, 1 \mathrm{H})$, $4.28(\mathrm{~s}, 5 \mathrm{H}), 4.09(\mathrm{t}, J=2.5 \mathrm{~Hz}, 1 \mathrm{H}) ;{ }^{13} \mathrm{C}$ NMR $\left(126 \mathrm{MHz}, \mathrm{CDCl}_{3}\right) \delta$ 94.7, 89.2, 72.4, 69.7, 68.4, 66.0, 65.8, 3.7. HRMS (ESI-TOF) $\mathrm{m} / \mathrm{z}$ $[\mathrm{M}]^{+}$Calcd for $\mathrm{C}_{12} \mathrm{H}_{8} \mathrm{ClFel} 369.8703$; Found 369.8705 .

1-Fluoro-2-(iodoethynyl)ferrocene (9c). Cond. a: 9c $(25 \mathrm{mg}$, $42 \%)$ obtained from $4 c$ (0.167 mmol, $50 \mathrm{mg})$; Cond. $d$ : $9 c$ (54 mg, 93\%) obtained from 4c (0.163 mmol, $49 \mathrm{mg})$. Red solid. Mp: 63$65^{\circ} \mathrm{C} .{ }^{1} \mathrm{H}$ NMR $\left(500 \mathrm{MHz}, \mathrm{CDCl}_{3}\right) \delta 4.36(\mathrm{~m}, 1 \mathrm{H}), 4.31(\mathrm{~s}, 5 \mathrm{H}), 4.12$ (m, 1H), $3.84(\mathrm{~m}, 1 \mathrm{H}) ;{ }^{13} \mathrm{C}$ NMR $\left(126 \mathrm{MHz}, \mathrm{CDCl}_{3}\right) \delta 135.8(\mathrm{~d}, J=$ $275.9 \mathrm{~Hz}), 87.8(\mathrm{~d}, J=3.8 \mathrm{~Hz}), 71.4,65.2(\mathrm{~d}, J=1.3 \mathrm{~Hz}), 60.9(\mathrm{~d}, J=$ $4.0 \mathrm{~Hz}), 56.4(\mathrm{~d}, J=13.9 \mathrm{~Hz}), 55.3(\mathrm{~d}, J=12.6 \mathrm{~Hz}), 3.5 .{ }^{19} \mathrm{~F}$ NMR $(75$ $\mathrm{MHz}, \mathrm{CDCl}_{3}$ ) $\delta-186.7$. HRMS (ESI-TOF) $\mathrm{m} / \mathrm{z}[\mathrm{M}]^{+}$Calcd for $\mathrm{C}_{12} \mathrm{H}_{8} \mathrm{FFeI}$ 353.8999; Found 353.9000.

$\left(S_{\mathrm{Fc}}\right)-1-$ Fluoro-2-(iodoethynyl)ferrocene $\left(\left(S_{\mathrm{Fc}}\right)-9 \mathrm{c}\right)$. Cond. a: $\left(S_{\mathrm{Fc}}\right)-9 \mathrm{c}(59 \mathrm{mg}, 51 \%)$ obtained from $\left(S_{\mathrm{Fc}}\right)-4 \mathrm{c}(0.327 \mathrm{mmol}, 98$ mg). Red solid. Mp: $107-109^{\circ} \mathrm{C} .[\alpha]_{\mathrm{D}}^{20}=-10\left(\mathrm{c}=0.44, \mathrm{CHCl}_{3}\right)$. HRMS (ESI-TOF) m/z [M] ${ }^{+}$Calcd for $\mathrm{C}_{12} \mathrm{H}_{8} \mathrm{FFeI}$ 353.8999; Found 353.8983.

2-(Iodoethynyl)cyanoferrocene (9d). Cond. d: 9d (20 mg, 85\%) obtained from $4 \mathbf{d}(20 \mathrm{mg}, 0.065 \mathrm{mmol})$. Light sensitive red solid. Mp: $119-121^{\circ} \mathrm{C} .{ }^{1} \mathrm{H}$ NMR $\left(500 \mathrm{MHz}, \mathrm{CDCl}_{3}\right) \delta 4.67(\mathrm{~m}, 1 \mathrm{H}), 4.65(\mathrm{~m}$, $1 \mathrm{H}), 4.41(\mathrm{~m}, 1 \mathrm{H}), 4.40(\mathrm{~s}, 5 \mathrm{H}) ;{ }^{13} \mathrm{C}$ NMR $\left(126 \mathrm{MHz}, \mathrm{CDCl}_{3}\right) \delta 118.8$, 87.8, 74.1, 72.1, 70.8, 70.0, 55.8, 6.6. HRMS (ESI-TOF) m/z [M] ${ }^{+}$ Calcd for $\mathrm{C}_{13} \mathrm{H}_{8} \mathrm{Fe}$ IN 360.9045; Found 360.9037.

$\left(S_{\mathrm{Fc}}\right)-2$-(Iodoethynyl)cyanoferrocene $\left(\left(\boldsymbol{S}_{\mathrm{Fc}}\right)-9 \mathrm{~d}\right)$. Cond. $a$ : $\left(S_{\mathrm{Fc}}\right)-$ 9d (60 mg, 77\%) obtained from $\left(S_{\mathrm{FC}}\right)-\mathbf{4 d}(0.217 \mathrm{mmol}, 67 \mathrm{mg})$. Light sensitive red solid. Mp: $150-152^{\circ} \mathrm{C} .[\alpha]_{\mathrm{D}^{20}}=+65(\mathrm{c}=0.5$, $\mathrm{CHCl}_{3}$ ). HRMS (ESI-TOF) m/z [M] ${ }^{+}$Calcd for $\mathrm{C}_{13} \mathrm{H}_{8} \mathrm{FeIN} 360.9045$; Found 360.9042.

1-Bromo-3-(iodoethynyl)ferrocene (10a). Cond. a: 10a (24 mg, $84 \%)$ obtained from 5a (0.069 mmol, $25 \mathrm{mg})$. Red oil. ${ }^{1} \mathrm{H}$ NMR $\left(500 \mathrm{MHz}, \mathrm{CDCl}_{3}\right) \delta 4.69$ (br s, $\left.1 \mathrm{H}\right), 4.44$ (br s, $\left.1 \mathrm{H}\right), 4.38$ (br s, $\left.1 \mathrm{H}\right)$, 4.29 (s, 5H); ${ }^{13} \mathrm{C}$ NMR (126 MHz, $\left.\mathrm{CDCl}_{3}\right) \delta 90.5,77.0,73.5,72.7$, $70.9,65.3,1.4$. HRMS (ESI-TOF) $\mathrm{m} / \mathrm{z}[\mathrm{M}]+$ Calcd for $\mathrm{C}_{12} \mathrm{H}_{8} \mathrm{BrFeI}$ 413.8200; Found 413.8190 .

$\left(S_{\mathrm{Fc}}\right)-1-B r o m o-3-(i o d o e t h y n y l) f e r r o c e n e ~\left(\left(S_{\mathrm{Fc}}\right)-10 a\right)$. Cond a: $\left(S_{\mathrm{Fc}}\right)-10 a\left(72 \mathrm{mg}, 38 \%\right.$ for 2 steps) obtained from $\left(S_{\mathrm{Fc}}\right)$-41. Red oil. HRMS (ESI-TOF) m/z [M]+ Calcd for $\mathrm{C}_{12} \mathrm{H}_{8} \mathrm{BrFeI}$ 413.8200; Found 413.8188.

1-Chloro-3-(iodoethynyl)ferrocene (10b). Cond. $a$ : 10b $(29 \mathrm{mg}$, $50 \%)$ obtained from $\mathbf{5 b}(0.158 \mathrm{mmol}, 50 \mathrm{mg})$; Cond. c: $\mathbf{1 0 b}(54$ $\mathrm{mg}, 78 \%)$ obtained from 15 (0.188 mmol, $46 \mathrm{mg})$; Method B: $\mathbf{9 b}$ (63 mg, 80\%) obtained from $\mathbf{5 b}(0.212 \mathrm{mmol}, 67 \mathrm{mg})$. Red oil. ${ }^{1} \mathrm{H}$ NMR $\left(500 \mathrm{MHz}, \mathrm{CDCl}_{3}\right) \delta 4.67(\mathrm{~m}, 1 \mathrm{H}), 4.41(\mathrm{~m}, 1 \mathrm{H}), 4.34(\mathrm{~m}, 1 \mathrm{H})$, $4.30(\mathrm{~s}, 5 \mathrm{H}) ;{ }^{13} \mathrm{C} \mathrm{NMR}\left(126 \mathrm{MHz} \mathrm{CDCl}_{3}\right) \delta 92.0,90.7,72.4,71.2$ 69.9, 68.6, 64.1, 1.1; HRMS (ESI-TOF) $\mathrm{m} / \mathrm{z}[\mathrm{M}]^{+}$Calcd for $\mathrm{C}_{12} \mathrm{H}_{8} \mathrm{ClFe} 369.8703$; Found 369.8689.

1-Fluoro-3-(iodoethynyl)ferrocene (10c). Cond. $a$ : 10c $(17 \mathrm{mg}$, $36 \%)$ obtained from $4 \mathbf{c}(0.133 \mathrm{mmol}, 40 \mathrm{mg})$; Cond. $d$ : 10c (105 $\mathrm{mg}, 80 \%)$ obtained from $4 \mathrm{c}(0.37 \mathrm{mmol}, 111 \mathrm{mg})$. Red oil. ${ }^{1} \mathrm{H}$ NMR $\left(500 \mathrm{MHz}, \mathrm{CDCl}_{3}\right) \delta 4.60(\mathrm{~m}, 1 \mathrm{H}), 4.34(\mathrm{~m}, 1 \mathrm{H}), 4.32(\mathrm{~s}, 5 \mathrm{H}), 4.12$ $(\mathrm{m}, 1 \mathrm{H}) ;{ }^{13} \mathrm{C}$ NMR $\left(126 \mathrm{MHz}, \mathrm{CDCl}_{3}\right) \delta 134.2(\mathrm{~d}, J=270.9 \mathrm{~Hz}), 91.1$, 94.4, 71.5, 65.1 (d, $J=2.4 \mathrm{~Hz}), 59.6(\mathrm{~d}, J=15.0 \mathrm{~Hz}), 59.2$ (d, $J=5.2$ $\mathrm{Hz}), 57.0(\mathrm{~d}, J=14.7 \mathrm{~Hz}), 0.2 ;{ }^{19} \mathrm{~F}$ NMR $\left(75 \mathrm{MHz}, \mathrm{CDCl}_{3}\right) \delta-185.8$. HRMS (ESI-TOF) $\mathrm{m} / \mathrm{z}$ [M] ${ }^{+}$Calcd for $\mathrm{C}_{12} \mathrm{H}_{8} \mathrm{FFe} 353.8999$; Found 353.8986.

1-(Iodoethynyl)-2-phenylferrocene (11a). Cond. a: 11a (74 mg, $72 \%)$ obtained from $6 \mathbf{6 a}(0.25 \mathrm{mmol}, 90 \mathrm{mg})$. Red oil. ${ }^{1} \mathrm{H}$ NMR (500 $\left.\mathrm{MHz} \mathrm{CDCl}_{3}\right) \delta 7.78(\mathrm{dd}, J=8.0,1.5 \mathrm{~Hz}, 2 \mathrm{H}), 7.36(\mathrm{t}, J=8.0 \mathrm{~Hz}, 2 \mathrm{H})$, $7.28(\mathrm{dt}, J=7.5,1.5 \mathrm{~Hz}, 1 \mathrm{H}), 4.61(\mathrm{~m}, 2 \mathrm{H}), 4.32(\mathrm{t}, J=3.0 \mathrm{~Hz}, 1 \mathrm{H})$, $4.15(\mathrm{~s}, 5 \mathrm{H}) ;{ }^{13} \mathrm{C}$ NMR $\left(126 \mathrm{MHz}, \mathrm{CDCl}_{3}\right) \delta 137.7,128.2,127.9$, $126.7,92.1,88.3,73.3,71.7,68.6,68.5,64.7,2.1$. HRMS (ESI-TOF) $\mathrm{m} / \mathrm{z}[\mathrm{M}]+{ }^{+}$Calcd for $\mathrm{C}_{18} \mathrm{H}_{13} \mathrm{FeI} 411.9406$; Found 411.9404 .

$\left(S_{\mathrm{Fc}}\right)-1-(I o d o e t h y n y)-2-p h e n y l f e r r o c e n e ~\left(\left(S_{\mathrm{Fc}}\right)-11 \mathrm{a}\right)$. Cond. a: $\left(S_{\mathrm{Fc}}\right)$-11a $(81 \mathrm{mg}, 59 \%)$ obtained from $\left(S_{\mathrm{Fc}}\right)-\mathbf{6 a}(0.335 \mathrm{mmol}, 120$ mg). Red solid. Mp: $92-94^{\circ} \mathrm{C} .[\alpha]_{\mathrm{D}^{20}}=+42\left(\mathrm{c}=0.4, \mathrm{CHCl}_{3}\right)$. HRMS (ESI-TOF) $\mathrm{m} / \mathrm{z}$ [M] ${ }^{+}$Calcd for $\mathrm{C}_{18} \mathrm{H}_{13} \mathrm{FeI}$ 411.9406; Found 411.9387.

1-(Iodoethynyl)-2-(naphthalene-2-yl)ferrocene (11b). Cond. a: 11b (73 mg, 63\%) obtained from $\mathbf{6 b}(0.25 \mathrm{mmol}, 102 \mathrm{mg})$. Red solid. Mp: $114-116^{\circ} \mathrm{C} .{ }^{1} \mathrm{H}$ NMR $\left(500 \mathrm{MHz}, \mathrm{CDCl}_{3}\right) \delta 8.21(\mathrm{~s}, 1 \mathrm{H})$, $7.93(\mathrm{~d}, J=8.5 \mathrm{~Hz}, 1 \mathrm{H}), 7.84(\mathrm{~m}, 3 \mathrm{H}), 7.47(\mathrm{~m}, 2 \mathrm{H}), 4.73(\mathrm{br} \mathrm{s}, 1 \mathrm{H})$, 4.66 (br s, $1 \mathrm{H}), 4.38(\mathrm{~m}, 1 \mathrm{H}), 4.16(\mathrm{~s}, 5 \mathrm{H}) ;{ }^{13} \mathrm{C}$ NMR $(126 \mathrm{MHz}$, $\left.\mathrm{CDCl}_{3}\right) \delta 135.3,133.5,132.5,128.0,127.8,127.6,126.6,126.3$, 125.9, 125.8, 92.3, 88.1, 73.5, 71.7, 68.8, 68.7, 64.8, 2.3. Mp: 126$128{ }^{\circ} \mathrm{C}$. HRMS (ESI-TOF) $\mathrm{m} / \mathrm{z}[\mathrm{M}]+$ Calcd for $\mathrm{C}_{22} \mathrm{H}_{15} \mathrm{Fel}$ 461.9562; Found 461.9547 . 
$\left(S_{\mathrm{Fc}}\right)$-1-(Iodoethynyl)-2-(naphthalene-2-yl)ferrocene $\quad\left(\left(S_{\mathrm{Fc}}\right)\right.$ 11b). Cond. a: $\left(S_{\mathrm{Fc}}\right)-11 \mathbf{b}(137 \mathrm{mg}, 67 \%)$ obtained from $\left(S_{\mathrm{Fc}}\right)-\mathbf{6 b}$ $(0.44 \mathrm{mmol}, 180 \mathrm{mg})$. Red solid. Mp: $127-129^{\circ} \mathrm{C} .[\alpha]_{\mathrm{D}^{20}}=+90(\mathrm{c}=$ $0.4, \mathrm{CHCl}_{3}$ ). HRMS (ESI-TOF) $\mathrm{m} / \mathrm{z}[\mathrm{M}]^{+}$Calcd for $\mathrm{C}_{22} \mathrm{H}_{15} \mathrm{FeI}$ 461.9562; Found 461.9541.

1-(Iodoethynyl)-3-phenylferrocene (12a). Cond. $a$ : 12a (10 mg, $45 \%)$ obtained from 7 a $(0.053 \mathrm{mmol}, 19 \mathrm{mg})$. Red solid. Mp: 120 $122^{\circ} \mathrm{C} .{ }^{1} \mathrm{H}$ NMR $\left(500 \mathrm{MHz}, \mathrm{CDCl}_{3}\right) \delta 7.42$ (dd, $\left.J=8.0,1.5 \mathrm{~Hz}, 2 \mathrm{H}\right)$, $7.27(\mathrm{t}, J=8.0 \mathrm{~Hz}, 2 \mathrm{H}), 7.19(\mathrm{dt}, J=7.5,1.5 \mathrm{~Hz}, 1 \mathrm{H}), 4.90(\mathrm{t}, J=1.5$ $\mathrm{Hz}, 1 \mathrm{H}), 4.64$ (dd, $J=2.5,1.5 \mathrm{~Hz}, 1 \mathrm{H}), 4.57$ (dd, $J=2.5,1.5 \mathrm{~Hz}, 1 \mathrm{H}$ ), $4.09(\mathrm{~s}, 5 \mathrm{H}) ;{ }^{13} \mathrm{C}$ NMR $\left(126 \mathrm{MHz}, \mathrm{CDCl}_{3}\right) \delta 138.0,128.6,126.6$, $126.3,91.9,86.3,72.6,71.7,70.1,67.2,66.5,0.0$. HRMS (ESI-TOF) $\mathrm{m} / \mathrm{z}[\mathrm{M}]^{+}$Calcd for $\mathrm{C}_{18} \mathrm{H}_{13} \mathrm{FeI}$ 411.9406; Found 411.9391 .

$\left(S_{\mathrm{Fc}}\right)-1-\left(\right.$ Iodoethynyl)-3-phenylferrocene $\left(\left(S_{\mathrm{Fc}}\right)-12 \mathrm{a}\right)$. Cond. a: $\left(S_{\mathrm{Fc}}\right)$-12a (65 mg, 56\%) obtained from $\left(S_{\mathrm{Fc}}\right)$-7a $(0.28 \mathrm{mmol}, 100$ mg). Red solid. Mp: $132-134^{\circ} \mathrm{C} .[\alpha]_{\mathrm{D}^{20}}=+33\left(\mathrm{c}=0.5, \mathrm{CHCl}_{3}\right)$. HRMS (ESI-TOF) $\mathrm{m} / \mathrm{z}$ [M] ${ }^{+}$Calcd for $\mathrm{C}_{18} \mathrm{H}_{13} \mathrm{FeI}$ 411.9406; Found 411.9400 .

1-(Iodoethynyl)-3-(naphthalene-2-yl)ferrocene (12b). Cond. a: 12b (8 mg, 44\%) obtained from $7 \mathbf{b}(0.039 \mathrm{mmol}, 16 \mathrm{mg})$. Red solid. Mp: $66-68^{\circ} \mathrm{C} .{ }^{1} \mathrm{H}$ NMR $\left(500 \mathrm{MHz}, \mathrm{CDCl}_{3}\right) \delta 7.84(\mathrm{~s}, 1 \mathrm{H}), 7.79$ $(\mathrm{t}, J=8.0 \mathrm{~Hz}, 3 \mathrm{H}), 7.60(\mathrm{dd}, \mathrm{J}=8.5,1.5 \mathrm{~Hz}, 1 \mathrm{H}), 7.46(\mathrm{~m}, 2 \mathrm{H}), 5.05$ (br s, 1H), $4.79(\mathrm{~m}, 1 \mathrm{H}), 4.65(\mathrm{~m}, 1 \mathrm{H}), 4.13(\mathrm{~s}, 5 \mathrm{H}) ;{ }^{13} \mathrm{C}$ NMR $(126$ $\left.\mathrm{MHz}, \mathrm{CDCl}_{3}\right) \delta 135.6,133.7,132.4,128.1,127.9,127.7,126.5$, 125.7, 125.1, 124.6, 91.9, 86.1, 72.9, 71.7, 70.2, 67.2, 66.8, 0.2. HRMS (ESI-TOF) m/z [M] ${ }^{+}$Calcd for $\mathrm{C}_{22} \mathrm{H}_{15} \mathrm{FeI}$ 461.9562; Found 461.9554.

( $\left.S_{\mathrm{Fc}}\right)$-1-(Iodoethynyl)-3-(naphthalene-2-yl)ferrocene $\quad\left(\left(S_{\mathrm{Fc}}\right)-\right.$ 12b). Cond. a: $\left(S_{\mathrm{Fc}}\right)-12 \mathbf{b}(55 \mathrm{mg}, 49 \%)$ obtained from $\left(S_{\mathrm{Fc}}\right)-7 \mathbf{b}$ (0.28 mmol, $100 \mathrm{mg})$; Cond. $d:\left(S_{\mathrm{Fc}}\right)-\mathbf{1 2 b}(14 \mathrm{mg}, 62 \%)$ obtained from $\left(S_{\mathrm{Fc}}\right)-7 \mathbf{b}(0.049 \mathrm{mmol}, 20 \mathrm{mg})$. Red solid. Mp: $68-70^{\circ} \mathrm{C} .[\alpha]_{\mathrm{D}}{ }^{20}$ $=+60\left(\mathrm{c}=0.3, \mathrm{CHCl}_{3}\right)$. HRMS (ESI-TOF) $\mathrm{m} / \mathrm{z}[\mathrm{M}]^{+}$Calcd for $\mathrm{C}_{22} \mathrm{H}_{15} \mathrm{FeI} 461.9562$; Found 461.9559.

1-(Iodoethynyl)-2-methylferrocene (13). Cond. a: 13 (47 mg, $50 \%)$ obtained from $8(0.27 \mathrm{mmol}, 80 \mathrm{mg})$. Red solid. Mp: 93$95^{\circ} \mathrm{C} .{ }^{1} \mathrm{H}$ NMR $\left(500 \mathrm{MHz}, \mathrm{CDCl}_{3}\right) \delta 4.35$ (dd, $\left.J=2.5,1.5 \mathrm{~Hz}, 1 \mathrm{H}\right)$, $4.14(\mathrm{~m}, 1 \mathrm{H}), 4.13(\mathrm{~s}, 5 \mathrm{H}), 4.04(\mathrm{t}, J=2.5 \mathrm{~Hz}, 1 \mathrm{H}), 2.09(\mathrm{~s}, 3 \mathrm{H}) ;{ }^{13} \mathrm{C}$ NMR $\left(126 \mathrm{MHz}, \mathrm{CDCl}_{3}\right) \delta 91.8,87.2,70.8,70.7,69.6,67.0,66.5$, 13.8, 0.3. HRMS (ESI-TOF) $\mathrm{m} / \mathrm{z}$ [M] ${ }^{+}$Calcd for $\mathrm{C}_{13} \mathrm{H}_{11} \mathrm{FeI} 349.9249$; Found 349.9236.

$\left(R_{\mathrm{Fc}}\right)-1-\left(\right.$ Iodoethynyl)-2-methylferrocene $\left(\left(R_{\mathrm{Fc}}\right)-13\right)$. Cond. a: $\left(R_{\mathrm{Fc}}\right)-13$ (46 mg, 39\%) obtained from $\left(R_{\mathrm{Fc}}\right)-\mathbf{8}(0.338 \mathrm{mmol}, 100$ $\mathrm{mg})$; Cond. $d:\left(R_{\mathrm{Fc}}\right)-\mathbf{1 3}(12 \mathrm{mg}, 73 \%)$ obtained from $\left(R_{\mathrm{Fc}}\right)-\mathbf{8}(0.047$ mmol, $14 \mathrm{mg}$ ). Red solid. Mp: $153-155^{\circ} \mathrm{C} .[\alpha]_{\mathrm{D}^{20}}=-9(\mathrm{c}=0.47$, $\mathrm{CHCl}_{3}$ ). HRMS (ESI-TOF) m/z [M] ${ }^{+}$Calcd for $\mathrm{C}_{13} \mathrm{H}_{11} \mathrm{FeI} 349.9249$; Found 349.9233.

General procedure for the alkyne sulfanylation. The alkyne (1 eq.) was dissolved in THF ( $2 \mathrm{~mL} / \mathrm{mmol})$ and the solution was cooled to $-78^{\circ} \mathrm{C} . n$-BuLi (1.6 M, 1 eq.) was added and stirring was continued for $1 \mathrm{~h}$. A solution of $N$-methyl- $N$ [(trifluoromethyl)sulfanyl]aniline (1 eq.) in THF $(0.5 \mathrm{~mL} / \mathrm{mmol})$ was added ad the mixture was stirred at $-78^{\circ} \mathrm{C}$ for $3 \mathrm{~h} . \mathrm{HCl} 6 \mathrm{M}$ was added and the mixture was extracted with pentane, washed with $\mathrm{HCl} 6 \mathrm{M}$ and water, and dried over $\mathrm{Na}_{2} \mathrm{SO}_{4}$. After filtration and concentration, the crude was purified by chromatography on silica gel (pentane) to give the expected product.

((2-Chloroferrocenyl)ethynyl)(trifluoromethyl)sulfane

(16a). Red oil (47 mg, 68\%) obtained from $14(0.2 \mathrm{mmol}, 49 \mathrm{mg})$. ${ }^{1} \mathrm{H}$ NMR $\left(500 \mathrm{MHz}, \mathrm{CDCl}_{3}\right) \delta 4.56(\mathrm{dd}, J=2.5,1.5 \mathrm{~Hz}, 1 \mathrm{H}$ ), 4.47 (dd, $J=2.5,1.5 \mathrm{~Hz}, 1 \mathrm{H}), 4.29(\mathrm{~s}, 5 \mathrm{H}), 4.20(\mathrm{t}, J=2.5 \mathrm{~Hz}, 1 \mathrm{H}) ;{ }^{13} \mathrm{C} \mathrm{NMR}$ $\left(126 \mathrm{MHz}, \mathrm{CDCl}_{3}\right) \delta 127.8(\mathrm{q}, J=313.7 \mathrm{~Hz}), 99.4,95.5,72.6,70.6$, 69.6, 67.2, $66.2(\mathrm{~d}, J=4.2 \mathrm{~Hz}), 62.6 .{ }^{19} \mathrm{~F}$ NMR $\left(75 \mathrm{MHz}, \mathrm{CDCl}_{3}\right) \delta-$ 44.4. HRMS (ESI-TOF) $\mathrm{m} / \mathrm{z}$ [M] ${ }^{+}$Calcd for $\mathrm{C}_{13} \mathrm{H}_{8} \mathrm{ClF}_{3} \mathrm{FeS} 343.9331$; Found 343.9352.

((3-Chloroferrocenyl)ethynyl)(trifluoromethyl)sulfane

(16b). Red oil (22 mg, 52\%) obtained from $15(0.123 \mathrm{mmol}, 30$ mg). ${ }^{1} \mathrm{H}$ NMR (500 MHz, $\left.\mathrm{CDCl}_{3}\right) \delta 4.76(\mathrm{br} \mathrm{s}, 1 \mathrm{H}), 4.52(\mathrm{br} \mathrm{s}, 1 \mathrm{H})$, 4.44 (br s, 1H), 4.31 (s, 5H); ${ }^{13} \mathrm{C}$ NMR $\left(126 \mathrm{MHz} \mathrm{CDCl}_{3}\right) \delta 127.8(\mathrm{q}$, $J=313.4 \mathrm{~Hz}), 101.0,92.8,72.5,72.0,71.0,69.9,63.6(\mathrm{~d}, J=4.3 \mathrm{~Hz})$,
60.8. $\left.{ }^{19} \mathrm{~F} \mathrm{NMR} \mathrm{(75} \mathrm{MHz,} \mathrm{CDCl}_{3}\right) \delta-44.4$. HRMS (ESI-TOF) $\mathrm{m} / \mathrm{z}[\mathrm{M}]^{+}$ Calcd for $\mathrm{C}_{13} \mathrm{H}_{8} \mathrm{ClF}_{3} \mathrm{FeS} 343.9331$; Found 343.9332 .

General procedure for the alkyne selenation. In a first flask under argon were added benzyl(trifluoromethyl)selane (1 eq.) and THF ( $1 \mathrm{~mL} / \mathrm{mmol})$. Sulfuryl chloride (1 eq.) was added at room temperature and the mixture was stirred for $15 \mathrm{~min}$ then cooled to $-78^{\circ} \mathrm{C}$. In a second flask, alkyne $(1.5$ eq.) was dissolved in THF $(2 \mathrm{~mL} / \mathrm{mmol})$ and the solution was cooled to $-78^{\circ} \mathrm{C} . n$-BuLi (1.4 $\mathrm{M}$ in hexanes, 1.4 eq.) was added and the mixture was stirred for $1 \mathrm{~h}$. The alkynyllithium solution was cannulated to the first flask at $-78^{\circ} \mathrm{C}$. After stirring for $10 \mathrm{~min}$, the temperature was raised to ambient. Water was added and the mixture was extracted with $\mathrm{Et}_{2} \mathrm{O}$, and dried over $\mathrm{Na}_{2} \mathrm{SO}_{4}$. After filtration and concentration, the crude was purified by chromatography on silica gel (pentane) to give the expected product.

((2-Chloroferrocenyl)ethynyl)(trifluoromethyl)selane (17a). Red oil (104 mg, 71\% based on benzyl(trifluoromethyl)selane) obtained from $14(0.558 \mathrm{mmol}, 136 \mathrm{mg})$, benzyl(trifluoromethyl)selane $(0.372 \mathrm{mmol}, 88 \mathrm{mg})$ and sulfuryl chloride $(0.372 \mathrm{mmol}, 30 \mu \mathrm{L}) .{ }^{1} \mathrm{H}$ NMR $\left(500 \mathrm{MHz}, \mathrm{CDCl}_{3}\right) \delta 4.55$ (br s, 1H), 4.46 (br s, 1H), 4.29 (s, 5H), 4.19 (t, J = 2.5 Hz, 1H); ${ }^{13} \mathrm{C}$ $\operatorname{NMR}\left(126 \mathrm{MHz}, \mathrm{CDCl}_{3}\right) \delta 120.3(\mathrm{q}, J=337.4 \mathrm{~Hz}), 104.7,95.3,72.5$, 70.3, 69.3, 67.0, 63.3, 61.3 (d, $J=3.2 \mathrm{~Hz}) .{ }^{19} \mathrm{~F}$ NMR $\left(75 \mathrm{MHz}, \mathrm{CDCl}_{3}\right)$ $\delta$-36.9. HRMS (ESI-TOF) $\mathrm{m} / \mathrm{z}[\mathrm{M}]^{+}$Calcd for $\mathrm{C}_{13} \mathrm{H}_{8} \mathrm{ClF}_{3} \mathrm{FeSe}$ 391.8776; Found 391.8793.

((3-Chloroferrocenyl)ethynyl)(trifluoromethyl)selane (17b). The general procedure was performed on $15(0.131 \mathrm{mmol}, 32$ $\mathrm{mg})$, benzyl(trifluoromethyl)selane $(0.087 \mathrm{mmol}, 21 \mathrm{mg})$ and sulfuryl chloride $(0.087 \mathrm{mmol}, 5.7 \mu \mathrm{L})$. After purification, the mixture $\left(27 \mathrm{mg}\right.$ ) was dissolved in DMSO $(2 \mathrm{~mL})$ and $\mathrm{LiOH}_{\mathrm{H}} \mathrm{H}_{2} \mathrm{O}$ ( $0.66 \mathrm{mmol}, 28 \mathrm{mg}$ ) was added. After stirring for $4 \mathrm{~h}$, the mixture was poured on ice and extracted with $\mathrm{Et}_{2} \mathrm{O}$. After drying over $\mathrm{Na}_{2} \mathrm{SO}_{4}$, filtration and concentration, the crude was purified by chromatography on silica gel (pentane) to give $\mathbf{1 7 b}(15 \mathrm{mg}, 44 \%$ based on benzyl(trifluoromethyl)selane) as a red solid. Mp: 36$38^{\circ} \mathrm{C} .{ }^{1} \mathrm{H}$ NMR $\left(500 \mathrm{MHz}, \mathrm{CDCl}_{3}\right) \delta 4.75$ (br s, $\left.1 \mathrm{H}\right), 4.51$ (br s, $1 \mathrm{H}$ ), 4.43 (br s, $1 \mathrm{H}), 4.31(\mathrm{~s}, 5 \mathrm{H}) ;{ }^{13} \mathrm{C}$ NMR $\left(126 \mathrm{MHz}, \mathrm{CDCl}_{3}\right) \delta 120.3(\mathrm{q}$, $J=337.3 \mathrm{~Hz}), 106.4,92.7,72.5,71.8,70.7,69.7,61.5,61.3(\mathrm{~d}, J=$ $5.0 \mathrm{~Hz}$ ). ${ }^{19} \mathrm{~F}$ NMR $\left(75 \mathrm{MHz}, \mathrm{CDCl}_{3}\right) \delta$-36.9. HRMS (ESI-TOF) $\mathrm{m} / \mathrm{z}$ $[\mathrm{M}]^{+}$Calcd for $\mathrm{C}_{13} \mathrm{H}_{8} \mathrm{ClF}_{3} \mathrm{FeSe}$ 391.8776; Found 391.8771.

General procedure for the Ritter reaction. Benzhydryl bromide $32(0.04 \mathrm{mmol}, 9.9 \mathrm{mg}$ ) was placed in a flask under argon. $2 \mathrm{~mL}$ of a stock solution (prepared by mixing $30 \mathrm{~mL}$ of $\mathrm{CH}_{3} \mathrm{CN}$ and $14.4 \mu \mathrm{L}$ of $\mathrm{H}_{2} \mathrm{O}$ ) was added followed by a solution of iodoalkyne activator $(0.04 \mathrm{mmol})$ in $1 \mathrm{~mL}$ of the same stock solution (note: iodoalkyne 11b was not soluble in $\mathrm{CH}_{3} \mathrm{CN}$ and was added as a solid). After stirring for $10 \mathrm{~h}$ at room temperature, the mixture was filtered on Celite and evaporated. The residue was analyzed by ${ }^{1} \mathrm{H}$ NMR in $\mathrm{CD}_{3} \mathrm{CN}$ (see spectra in Supporting Information).

General procedure for benzoxazole synthesis. Thioacetamide $34(0.2 \mathrm{mmol}, 15 \mathrm{mg})$, 2-aminophenol ( $0.4 \mathrm{mmol}, 43.6 \mathrm{mg}$ ) and the catalyst $(0.02 \mathrm{mmol})$ were placed in a resealable tube under argon. Degassed toluene $(0.4 \mathrm{~mL})$ was added and the mixture was stirred for $15 \mathrm{~h}$ at $90^{\circ} \mathrm{C}$. After cooling to room temperature, the crude was filtered on Celite, washed with diethyl ether and concentrated with a rotavapor at $20^{\circ} \mathrm{C}$ (the use of high vacuum must be avoided). $1 \mathrm{~mL}$ of a $0.2 \mathrm{M}$ solution of DMF in dichloromethane was added. Dichloromethane was removed with a rotavapor at $20^{\circ} \mathrm{C}$ and the residue was analyzed by ${ }^{1} \mathrm{H}$ NMR (see spectra in Supporting Information).

X-ray Structure Determination. X-ray crystallographic data were collected at low temperature on CCD or CMOS diffractometers using $\operatorname{Mo}(\mathrm{K} \alpha)$ radiation.

Crystal Data for $\left(\boldsymbol{S}_{\mathrm{Fc}}\right)-9 \mathrm{a} . \mathrm{C}_{12} \mathrm{H}_{8} \mathrm{BrFeI}$. M $=414.84$, monoclinic, $a=$ 8.0567(7) $\AA, b=9.2384(8) \AA, c=8.9782(7) \AA, \beta=115.956(3)^{\circ}, \mathrm{V}$ $=600.85(9) \AA^{3}, \mathrm{~T}=100(2) \mathrm{K}$, space group $P 2_{1}, Z=2, \mu(\mathrm{Mo} \mathrm{K} \alpha)=$ $7.111 \mathrm{~mm}^{-1}, 30382$ reflections measured, 5746 independent reflections $\left(\mathrm{R}_{\mathrm{int}}=0.0394\right)$. Flack parameter $=0.007(9)$. The final $\mathrm{R}_{1}$ values were $0.0224(\mathrm{I}>2 \sigma(\mathrm{I}))$ and 0.0241 (all data). The final $\mathrm{wR}\left(\mathrm{F}^{2}\right)$ values 
were $0.0533(\mathrm{I}>2 \sigma(\mathrm{I}))$ and 0.0540 (all data). The goodness of fit on $\mathrm{F}^{2}$ was 1.041. CCDC no. 1995956.

Crystal Data for $\left(\boldsymbol{S}_{\mathrm{Fc}}\right)-9 \mathrm{c}$. $\mathrm{C}_{12} \mathrm{H}_{8} \mathrm{FFeI} . \mathrm{M}=353.93$, orthorhombic, $a$ $=16.4655(16) \AA, b=8.9985(8) \AA, c=7.3936(7) \AA, \mathrm{V}=$ 1095.47(18) $\AA^{3}, \mathrm{~T}=100(2) \mathrm{K}$, space group $P 2{ }_{1} 2_{1} 2_{1}, Z=4, \mu($ Mo K $\alpha)$ $=4.168 \mathrm{~mm}^{-1}, 32379$ reflections measured, 5244 independent reflections $\left(R_{\text {int }}=0.0331\right)$. Flack parameter $=0.00(2)$. The final $R_{1}$ values were $0.0176(\mathrm{I}>2 \sigma(\mathrm{I}))$ and 0.0184 (all data). The final $\mathrm{wR}\left(\mathrm{F}^{2}\right)$ values were 0.0441 (I > $2 \sigma(\mathrm{I}))$ and 0.0444 (all data). The goodness of fit on $\mathrm{F}^{2}$ was 1.090. CCDC no. 1995957.

Crystal Data for 9c. $\mathrm{C}_{12} \mathrm{H}_{8} \mathrm{FFel} . \mathrm{M}=353.93$, orthorhombic, $a=$ 16.43910(10) $\AA, b=8.99930(10) \AA, c=7.41700(10) \AA, \mathrm{V}=$ 1097.27(2) $\AA^{3}, \mathrm{~T}=100(2) \mathrm{K}$, space group Pnma, $\mathrm{Z}=4, \mu(\mathrm{Mo} \mathrm{K} \alpha)=$ $4.161 \mathrm{~mm}^{-1}, 79465$ reflections measured, 2761 independent reflections $\left(R_{\text {int }}=0.0482\right)$. The final $R_{1}$ values were $0.0183(I>2 \sigma(I))$ and 0.0198 (all data). The final $w R\left(F^{2}\right)$ values were $0.0483(I>2 \sigma(I))$ and 0.0490 (all data). The goodness of fit on $\mathrm{F}^{2}$ was 1.090. CCDC no. 1995952

Crystal Data for $\left(\boldsymbol{S}_{\mathrm{Fc}}\right)-\mathbf{1 1 a} . \mathrm{C}_{18} \mathrm{H}_{13} \mathrm{FeI} . \mathrm{M}=412.03$, orthorhombic, $a=8.8955(9) \AA, b=10.9653(11) \AA, c=15.3106(17) \AA, \mathrm{V}=$ 1493.4(3) $\AA^{3}, T=100(2) \mathrm{K}$, space group $P 2{ }_{1} 2_{1} 2_{1}, Z=4, \mu(\mathrm{Mo} \mathrm{K \alpha})=$ $3.063 \mathrm{~mm}^{-1}, 190633$ reflections measured, 8528 independent reflections $\left(\mathrm{R}_{\text {int }}=0.0328\right)$. Flack parameter $=-0.017(14)$. The final $\mathrm{R}_{1}$ values were $0.0208(\mathrm{I}>2 \sigma(\mathrm{I}))$ and 0.0245 (all data). The final $w R\left(\mathrm{~F}^{2}\right)$ values were $0.0462(\mathrm{I}>2 \sigma(\mathrm{I}))$ and 0.0473 (all data). The goodness of fit on $\mathrm{F}^{2}$ was 1.072. CCDC no. 1995958.

Crystal Data for $\left(S_{\mathrm{Fc}}\right)-11 b . \mathrm{C}_{22} \mathrm{H}_{15} \mathrm{FeI} . \mathrm{M}=462.09$, orthorhombic, $a=8.4360(6) \AA, b=10.9150(7) \AA, c=19.1274(13) \AA, \mathrm{V}=$ 1761.2(2) $\AA^{3}, T=100(2) \mathrm{K}$, space group $P 2_{1} 2_{1} 2_{1}, Z=4, \mu(\mathrm{Mo} \mathrm{K \alpha})=$ $2.608 \mathrm{~mm}^{-1}, 28923$ reflections measured, 8376 independent reflections $\left(R_{\text {int }}=0.0342\right)$. Flack parameter $=-0.01(2)$. The final $R_{1}$ values were $0.0381(\mathrm{I}>2 \sigma(\mathrm{I}))$ and 0.0609 (all data). The final $w R\left(\mathrm{~F}^{2}\right)$ values were $0.0730(\mathrm{I}>2 \sigma(\mathrm{I}))$ and 0.0802 (all data). The goodness of fit on $\mathrm{F}^{2}$ was 1.033. CCDC no. 1995959.

Crystal Data for 11b. $\mathrm{C}_{22} \mathrm{H}_{15} \mathrm{FeI} . \mathrm{M}=462.09$, monoclinic, $a=$ 8.1177(2) $\AA, b=11.1905(2) \AA, c=18.9284(5) \AA, \beta=90.164(2){ }^{\circ}$, $\mathrm{V}=1719.47(7) \AA^{3}, \mathrm{~T}=100(2) \mathrm{K}$, space group $P 2_{1} / n, \mathrm{Z}=4, \mu(\mathrm{Mo}$ $\mathrm{K} \alpha)=2.671 \mathrm{~mm}^{-1}, 31600$ reflections measured, 5160 independent reflections $\left(R_{\text {int }}=0.0445\right)$. The final $R_{1}$ values were $0.0412(I>2 \sigma(I))$ and 0.0505 (all data). The final $w R\left(\mathrm{~F}^{2}\right)$ values were $0.0887(\mathrm{I}>2 \sigma(\mathrm{I}))$ and 0.0925 (all data). The goodness of fit on $\mathrm{F}^{2}$ was 1.064. CCDC no. 1995954

Crystal Data for $\left(S_{\mathrm{Fc}}\right)-12 \mathrm{a} . \mathrm{C}_{18} \mathrm{H}_{13} \mathrm{FeI} . \mathrm{M}=412.03$, monoclinic, $a=$ 9.7598(10) $\AA, b=7.8063(8) \AA, c=10.0468(11) \AA, \beta=105.676(4)$ $\circ, \mathrm{V}=736.97(13) \AA^{3}, \mathrm{~T}=100(2) \mathrm{K}$, space group $P 2_{1}, \mathrm{Z}=2, \mu(\mathrm{Mo}$ $\mathrm{K} \alpha)=3.103 \mathrm{~mm}^{-1}, 43287$ reflections measured, 7044 independent reflections $\left(R_{\text {int }}=0.0478\right)$. Flack parameter $=-0.01(2)$. The final $R_{1}$ values were $0.0330(\mathrm{I}>2 \sigma(\mathrm{I}))$ and 0.0461 (all data). The final $\mathrm{wR}\left(\mathrm{F}^{2}\right)$ values were $0.0588(\mathrm{I}>2 \sigma(\mathrm{I}))$ and 0.0620 (all data). The goodness of fit on $\mathrm{F}^{2}$ was 1.067. CCDC no. 1995960.

Crystal Data for $\left(\boldsymbol{R}_{\mathrm{Fc}}\right)-13 . \mathrm{C}_{13} \mathrm{H}_{11} \mathrm{FeI} . \mathrm{M}=349.97$, monoclinic, $a=$ 8.1541(11) $\AA, b=8.9666(12) \AA, c=9.0907(12) \AA, \beta=116.395(4)$ $\circ, \mathrm{V}=595.37(14) \AA^{3}, \mathrm{~T}=100(2) \mathrm{K}$, space group $P 2_{1}, \mathrm{Z}=2, \mu(\mathrm{Mo}$ $\mathrm{K} \alpha)=3.822 \mathrm{~mm}^{-1}, 61869$ reflections measured, 5702 independent reflections $\left(R_{\text {int }}=0.0333\right)$. Flack parameter $=0.007(12)$. The final $R_{1}$ values were $0.0118(\mathrm{I}>2 \sigma(\mathrm{I}))$ and 0.0121 (all data). The final $w R\left(\mathrm{~F}^{2}\right)$ values were $0.0318(\mathrm{I}>2 \sigma(\mathrm{I}))$ and 0.0319 (all data). The goodness of fit on $\mathrm{F}^{2}$ was 1.043. CCDC no. 1995953.

Crystal Data for 13. $\mathrm{C}_{13} \mathrm{H}_{11}$ FeI. $\mathrm{M}=349.97$, monoclinic, $a=$ $13.14030(10) \AA, b=12.99390(10) \AA, c=14.08200$ (10) $\AA, \beta=$ $103.6150(10)^{\circ}, \mathrm{V}=2336.85(3) \AA^{3}, \mathrm{~T}=100(2) \mathrm{K}$, space group $P 2{ }_{1} / c$, $\mathrm{Z}=8, \mu(\mathrm{Mo} \mathrm{K} \alpha)=3.895 \mathrm{~mm}^{-1}, 87060$ reflections measured, 11589 independent reflections $\left(R_{\text {int }}=0.0341\right)$. The final $R_{1}$ values were $0.0209(\mathrm{I}>2 \sigma(\mathrm{I}))$ and 0.0285 (all data). The final $\mathrm{wR}\left(\mathrm{F}^{2}\right)$ values were $0.0471(\mathrm{I}>2 \sigma(\mathrm{I}))$ and 0.0493 (all data). The goodness of fit on $\mathrm{F}^{2}$ was 1.046. CCDC no. 1995955.

\section{ASSOCIATED CONTENT}

\section{Supporting Information}

The Supporting Information is available free of charge on the ACS Publications website.

${ }^{1} \mathrm{H}$ and ${ }^{13} \mathrm{C}$ NMR spectra of all new compounds; HPLC and computational details; XRD details for structures of $S_{\mathrm{Fc}^{-}}-9 \mathrm{a}, S_{\mathrm{Fc}^{-}}$ 9c, 9c, $S_{\mathrm{Fc}}-11 \mathrm{a}, S_{\mathrm{Fc}}-11 \mathrm{~b}, 11 \mathrm{~b}, S_{\mathrm{Fc}}-12 \mathrm{a}, R_{\mathrm{Fc}}-13,13$ (PDF) and the corresponding cif files.

\section{Accession Codes}

CCDC 1995952-1995960 contain the supplementary crystallographic data for this paper. These data can be obtained free of charge

via www.ccdc.cam.ac.uk/data_request/cif,orbyemailingdata_requ est@ccdc.cam.ac.uk, or by contacting The Cambridge Crystallographic Data Centre, 12 Union Road, Cambridge CB2 1EZ, UK; fax: +44 1223336033

\section{AUTHOR INFORMATION}

\section{Corresponding Authors}

* E-mail for V.M.: vmamane@unistra.fr; e-mail for P.P.: paola.peluso@cnr.it

Notes

The authors declare no competing financial interest.

\section{ACKNOWLEDGMENT}

This work was supported by the CNRS and University of Strasbourg. P. Peluso and S.C. are grateful to Università Ca' Foscari Venezia, Italy (Dipartimento di Scienze Molecolari e Nanosistemi, DSMN ADIR funds). We thank the $\mathrm{PMD}^{2} \mathrm{X}$ X-ray diffraction facility of the Institut Jean Barriol, Universite de Lorraine, for X-ray diffraction measurements, data processing and analysis, and providing of reports for publication: http://crm2.univ-lorraine.fr/lab/fr/services/pmd2x). The EXPLOR mesocentre is thanked for providing access to computing facility (project 2019CPMXX0984/wbg13). We thank J. $\mathrm{N}$. Abergel for his help in the preparation of starting dihaloferrocenes.

\section{REFERENCES}

(1) Politzer, P.; Murray, J. S.; Clark, T. Halogen Bonding and other $\sigma$-Hole Interactions: a Perspective. Phys. Chem. Chem. Phys. 2013, 15, 11178-11189.

(2) Cavallo, G.; Metrangolo, P.; Milani, R.; Pilati, T.; Priimagi, A.; Resnati, G.; Terraneo, G. The Halogen Bond. Chem. Rev. 2016, 116, 2478-2601.

(3) Tepper, R.; Schubert, U.S. Halogen Bonding in Solution: Anion Recognition, Templated Self-Assembly, and Organocatalysis. Angew. Chem. Int. Ed. 2018, 57, 60046016.

(4) Vogel, L.; Wonner, P.; Huber, S.M. Chalcogen Bonding: An Overview. Angew. Chem. Int. Ed. 2019, 58, 1880-1891.

(5) Scilabra, P.; Terraneo, G.; Resnati, G. The Chalcogen Bond in Crystalline Solids: A World Parallel to Halogen Bond. Acc. Chem. Res. 2019, 52, 1313-1324.

(6) Lim, J.Y.C.; Beer, P.D. Sigma-Hole Interactions in Anion Recognition. Chem 2018, 4, 731-783.

(7) Sutar, R.; Huber, S. M. Catalysis of Organic Reactions through Halogen Bonding. ACS Catal. 2019, 9, 9622-9639.

(8) Bamberger, J.; Ostler, F.; García Mancheño, O. Frontiers in Halogen and Chalcogen-Bond Donor Organocatalysis. ChemCatChem 2019, 11, 5198-5211.

(9) Peluso, P.; Mamane, V.; Aubert, E.; Cossu, S. Insights into the Impact of Shape and Electronic Properties on The Enantioseparation of Polyhalogenated 4,4'-Bipyridines on Polysaccharide-Type Selectors. Evidence of 
Stereoselective Halogen Bonding Interactions. J. Chromatogr. A 2014, 1345, 182-192.

(10) Peluso, P.; Mamane, V.; Aubert, E.; Dessi, A.; Dallocchio, R.; Dore, A.; Pale, P.; Cossu, S. Insights into Halogen Bond Driven Enantioseparations. J. Chromatogr. A 2016, 1467, 228-238.

(11) Peluso, P.; Mamane, V.; Dallocchio, R.; Dessi, A.; Villano, R.; Sanna, D.; Aubert, E.; Pale, P.; Cossu, S. PolysaccharideBased Chiral Stationary Phases as Halogen Bond Acceptors: A Novel Strategy for Detection of Stereoselective $\sigma$ Hole Bonds in Solution. J. Sep. Sci. 2018, 41, 1247-1256.

(12) Dallocchio, R.; Dessi, A.; Solinas, M.; Arras, A.; Cossu, S.; Aubert, E.; Mamane, V.; Peluso, P. Halogen Bond in HighPerformance Liquid Chromatography Enantioseparations: Description, Features and Modelling. J. Chromatogr. A 2018, 1563, 71-81.

(13) Peluso, P.; Gatti, C.; Dessi, A.; Dallocchio, R.; Weiss, R.; Aubert, E.; Pale, P.; Cossu, S.; Mamane, V. Enantioseparation of Fluorinated 3-Arylthio-4,4'Bipyridines: Insights into Chalcogen and $\pi$-Hole Bonds in High-Performance Liquid Chromatography. J. Chromatogr. A 2018, 1567, 119-129.

(14) Peluso, P.; Mamane, V.; Dessì, A.; Dallocchio, R.; Aubert, E.; Gatti, C.; Mangelings, D.; Cossu, S. Halogen Bond in Separation Science: a Critical Analysis across Experimental and Theoretical Results. J. Chromatogr. A 2020, 1616, 460788.

(15) Lim, J.Y.C.; Marques, I.; Ferreira, L.; Félix, V.; Beer, P. D. Enhancing the Enantioselective Recognition and Sensing of Chiral Anions by Halogen Bonding. Chem. Comm. 2016, 52, 5527-5530.

(16) Borissov, A.; Lim, J.Y.C.; Brown, A.; Christensen, K. E.; Thompson, A. L.; Smith, M. D.; Beer, P. D. Neutral Iodotriazole Foldamers as Tetradentate Halogen Bonding Anion Receptors. Chem. Commun. 2017, 53, 2483-2486.

(17) Lim, J.Y.C.; Marques, I.; Félix, V.; Beer, P. D. Enantioselective Anion Recognition by Chiral HalogenBonding [2]Rotaxanes. J. Am. Chem. Soc. 2017, 139, 12228-12239.

(18) Lim, J.Y.C.; Marques, I.; Félix, V.; Beer, P. D. A Chiral Halogen-Bonding [3]Rotaxane for the Recognition and Sensing of Biologically Relevant Dicarboxylate Anions. Angew. Chem. Int. Ed. 2018, 57, 584-588.

(19) Kaasik, M.; Kaabel, S.; Kriis, K.; Järving, I.; Aav, R.; Rissanen, K.; Kanger, T. Synthesis and Characterisation of Chiral Triazole-Based Halogen-Bond Donors: Halogen Bonds in the Solid State and in Solution. Chem. Eur. J. 2017, 23, 7337-7344.

(20) Peterson, A.; Kaasik, M.; Metsala, A.; Jarving, I.; Adamson, J.; Kanger, T. Tunable Chiral Triazole-Based Halogen Bond Donors: Assessment of Donor Strength in Solution with Nitrogen-Containing Acceptors. RSC Adv. 2019, 9, 1171811721.

(21) Kuwano, S.; Suzuki, T.; Hosakaa, Y.; Arai, T. A Chiral Organic Base Catalyst with Halogen-Bonding-Donor Functionality: Asymmetric Mannich Reactions of Malononitrile with $\mathrm{N}$-Boc Aldimines and Ketimines. Chem. Comm. 2018, 54, 3847-3850.

(22) Kuwano, S.; Nishida, Y.; Suzuki, T.; Arai, T. Catalytic Asymmetric Mannich-Type Reaction of Malononitrile with $N$-Boc $\alpha$-Ketiminoesters Using Chiral Organic Base Catalyst with Halogen Bond Donor Functionality. Adv. Synth. Catal. 2020, 362, 1674-1678.

(23) Sutar, R. L.; Engelage, E.; Stoll, R.; Huber, S. M. Bidentate Chiral Bis(imidazolium)-Based Halogen-Bond Donors: Synthesis and Applications in Enantioselective Recognition and Catalysis. Angew. Chem. Int. Ed. 2020, 59, 68066810 .
(24) Weiss, R.; Aubert, E.; Peluso, P.; Cossu, S.; Pale, P.; Mamane, V. Chiral Chalcogen Bond Donors Based on the 4,4' Bipyridine Scaffold. Molecules 2019, 24, 4484.

(25) Goroff, N. S.; Curtis, S. M.; Webb, J. A.; Fowler, F. W.; Lauher, J. W. Designed Cocrystals Based on the Pyridine-Iodoalkyne Halogen Bond. Org. Lett. 2005, 7, 18911893.

(26) González, L.; Gimeno, N.; Tejedor, R. M.; Polo, V.; Ros, M. B.; Uriel, S.; Serrano, J. L. Halogen-Bonding Complexes Based on Bis(iodoethynyl)benzene Units: A New Versatile Route to Supramolecular Materials. Chem. Mater. 2013, $25,4503-4510$.

(27) Aakeröy, C. B.; Wijethunga, T. K.; Desper, J.; Đaković, M. Crystal Engineering with Iodoethynylnitrobenzenes: A Group of Highly Effective Halogen-Bond Donors. Cryst. Growth Des. 2015, 15, 3853-3861.

(28) Laurence, C.; Queignec-Cabanetos, M.; Dziembowska, T.; Queignec, R.; Wojtkowiak, B. 1-Iodoacetylenes. 1. Spectroscopic Evidence of Their Complexes with Lewis Bases. A Spectroscopic Scale of Soft Basicity. J. Am. Chem. Soc. 1981, 103, 2567-2573.

(29) Dumele, O.; Wu, D.; Trapp, N.; Goroff, N.; Diederich, F. Halogen Bonding of (Iodoethynyl)benzene Derivatives in Solution. Org. Lett. 2014, 16, 4722-4725.

(30) Matsuzawa, A.; Takeuchi, S.; Sugita, K. Iodoalkyne-Based Catalyst-Mediated Activation of Thioamides through Halogen Bonding. Chem. Asian. J. 2016, 11, 2863-2866.

(31) Perera, M. D.; Aakeröy, C. B. Organocatalysis by A Multidentate Halogen-Bond Donor: An Alternative to Hydrogen-Bond Based Catalysis. New J. Chem. 2019, 43, 8311-8314

(32) Sharma, P.; Singh, R. R.; Giri, S. S.; Chen, L.-Y.; Cheng, M.J.; Liu, R.-S. Gold-Catalyzed Oxidation of Thioalkynes to Form Phenylthio Ketene Derivatives via a Noncarbene Route. Org. Lett. 2019, 21, 5475-5479.

(33) Song, W.; Zheng, N.; Li, M.; He, J.; Li, J.; Dong, K.; Ullah, K.; Zheng, Y. Rhodium(I)-Catalyzed Regioselective Azideinternal Alkynyl Trifluoromethyl Sulfide Cycloaddition and Azide-internal Thioalkyne Cycloaddition under Mild Conditions. Adv. Synth. Catal. 2019, 361, 469-475.

(34) Coelho, F. L.; Gil, E. S.; Gonçalves, P. F. B.; Campo, L. F.; Schneider, P. H. Intramolecular Hydroamination of Selenoalkynes to 2-Selenylindoles in the Absence of Catalyst. Chem. Eur. J. 2019, 25, 8157-8162.

(35) Baldassari, L. L.; Mantovani, A. C.; Senoner, S.; Maryasin, B.; Maulide, N.; Lüdtke, D. S. Redox-Neutral Synthesis of Selenoesters by Oxyarylation of Selenoalkynes under Mild Conditions. Org. Lett. 2018, 20, 5881-5885.

(36) Schaarschmidt, D.; Lang, H. Selective Syntheses of PlanarChiral Ferrocenes. Organometallics 2013, 32, 5668-5704.

(37) Dai, L.-X.; Tu, T.; You, S.-L.; Deng, W.-P.; Hou, X.-L. Asymmetric Catalysis with Chiral Ferrocene Ligands. Acc. Chem. Res. 2003, 36, 659-667.

(38) Mamane, V. Metal-Catalyzed Cross-Coupling Reactions for Ferrocene Functionalization: Recent Applications in Synthesis, Material Science and Asymmetric Catalysis. MiniRev. Org. Chem. 2008, 5, 303-312.

(39) Kuklin, S. A.; Sheloumov, A. M.; Dolgushin, F. M.; Ezernitskaya, M. G.; Peregudov, A. S.; Petrovskii, P. V.; Koridze, A. A. Highly Active Iridium Catalysts for Alkane Dehydrogenation. Synthesis and Properties of Iridium Bis(phosphine) Pincer Complexes Based on Ferrocene and Ruthenocene. Organometallics 2006, 25, 5466-5476.

(40) Ferber, B.; Top, S.; Vessières, A.; Welter, R.; Jaouen, G. Synthesis of Optically Pure $o$-Formylcyclopentadienyl Metal Complexes of $17 \alpha$-Ethynylestradiol. Recognition of the Planar Chirality by the Estrogen Receptor. Organometallics 2006, 25, 5730-5739. 
(41) Westwood, J.; Coles, S. J.; Collinson, S. R.; Gasser, G.; Green, S. J.; Hursthouse, M. B.; Light, M. E.; Tucker, J. H. R. Binding and Electrochemical Recognition of Barbiturate and Urea Derivatives by a Regioisomeric Series of HydrogenBonding Ferrocene Receptors. Organometallics 2004, 23, 946-951.

(42) Lim, J. Y. C.; Beer, P. D. A Halogen Bonding 1,3Disubstituted Ferrocene Receptor for Recognition and Redox Sensing of Azide. Eur. J. Inorg. Chem. 2017, 220-224.

(43) Walter, S. M.; Kniep, F.; Herdtweck, E. Huber, S. M. Halogen-Bond-Induced Activation of a Carbon-Heteroatom Bond. Angew. Chem. Int. Ed. 2011, 50, 7187-7191

(44) Aakeröy, C. B.; Baldrighi, M.; Desper, J.; Metrangolo, P.; Resnati, G. Supramolecular Hierarchy among Halogen-Bond Donors. Chem. Eur. J. 2013, 19, 16240-16247.

(45) Torubaev, Y. V.; Skabitskya, I. V. The Energy Frameworks of aufbau Synthon Modules in 4-Cyanopyridine Cocrystals. CrystEngComm 2019, 21, 7057-7068.

(46) Torubaev, Y. V.; Skabitsky, I. V. The energy frameworks of aufbau synthon modules in 4-cyanopyridine co-crystals. CrystEngComm 2019, 21, 7057-7068.

(47) Dayaker, G.; Sreeshailam, A.; Chevallier, F.; Roisnel, T.; Krishna, P. R.; Mongin, F. Deprotonative Metallation of Ferrocenes using Mixed Lithium-Zinc and LithiumCadmium Combinations. Chem. Commun. 2010, 46, 28622864.

(48) Tazi, M.; Hedidi, M.; Erb, W.; Halauko, Y. S.; Ivashkevich, O. A.; Matulis, V. E.; Roisnel, T.; Dorcet, V.; Bentabed-Ababsa, G.; Mongin, F. Fluoro- and Chloroferrocene: From 2- to 3Substituted Derivatives. Organometallics 2018, 37, 22072211.

(49) Tazi, M.; Erb, W.; Roisnel, T.; Dorcet, V.; Mongin, F.; Low, P. J. From Ferrocene to fluorine-Containing Pentasubstituted Derivatives and all Points in-between; or, how to Increase the Available Chemical Space. Org. Biomol. Chem. 2019, 17, 9352-9359.

(50) Chinchilla, R.; Najera, C. The Sonogashira Reaction: A Booming Methodology in Synthetic Organic Chemistry. Chem. Rev. 2007, 107, 874-922.

(51) Inkpen, M. S.; White, A. J. P.; Albrecht, T.; Long, N. J. Rapid Sonogashira Cross-Coupling of Iodoferrocenes and the Unexpected Cyclo-Oligomerization of 4Ethynylphenylthioacetate. Chem. Commun. 2013, 49, 5663-5665.

(52) Wolfe, J. P.; Singer, R. A.; Yang, B. H.; Buchwald, S. L. Highly Active Palladium Catalysts for Suzuki Coupling Reactions. J. Am. Chem. Soc. 1999, 121, 9550-9561.

(53) Nishikawa, T.; Shibuya, S.; Hosokawa, S.; Isobe, M. One Pot Synthesis of Haloacetylenes from Trimethylsilylacetylenes. Synlett 1994, 485-486.

(54) Carty, P.; Dove, M. F. A. The Reaction of Some Ferrocenyl Ketones with Anhydrous Silver Tetrafluoroborate, a New Route to Substituted Ferricenium Salts. J. Organomet. Chem. 1971, 28, 125-132.

(55) Aguado, J. E.; Cativiela, C.; Gimeno, M. C.; Jones, P. G.; Laguna, A.; Sarroca, C. Unexpected Formation of FerroceneContaining Indolizines by Tandem Cyclization-Activation Reactions Induced by Silver Salts. Eur. J. Inorg. Chem. 2009, 216-219.

(56) Russo, M. V.; Sterzo, L.; Franceschini, P.; Biagini, G.; Furlani, A. Synthesis of Highly Ethynylated Mono and Dinuclear Pt(II) Tethers Bearing the 4,4'Bis(Ethynyl)Biphenyl (debp) Unit as Central Core. J. Organomet. Chem. 2001, 619, 49-61.

(57) Baert, F.; Colomb, J.; Billard, T. Electrophilic Trifluoromethanesulfanylation of Organometallic Species with Trifluoromethanesulfanamides. Angew. Chem. Int. Ed. 2012, 51, 10382-10385.
(58) Glenadel, Q.; Ismalaj, E.; Billard, T. Electrophilic Trifluoromethyl- and Fluoroalkylselenolation of Organometallic Reagents. Eur. J. Org. Chem. 2017, 530-533.

(59) Glenadel, Q.; Ismalaj, E.; Billard, T. A Metal-Free Route to Heterocyclic Trifluoromethyl- and Fluoroalkylselenolated Molecules. Org. Lett. 2018, 20, 56-59.

(60) Zhong, L.; Savoie, P. R.; Filatov, A. S.; Welch, J. T. Preparation and Characterization of Alkenyl Aryl Tetrafluoro-l6sulfanes. Angew. Chem. Int. Ed. 2014, 53, 526-529.

(61) Jiang, D.; He, T.; Ma, L.; Wang, Z. Recent Developments in Ritter Reaction. RSC Adv. 2014, 4, 64936-64946.

(62) Jagodzinski, T. Thioamides as Useful Synthons in the Synthesis of Heterocycles. Chem. Rev. 2003, 103, 197-228.

(63) Ritter, J. J.; Minieri, P. P. A New Reaction of Nitriles. I. Amides from Alkenes and Mononitriles. J. Am. Chem. Soc. 1948, 70, 4045-4048.

(64) For a review, see: Guérinot, A.; Reymond, S.; Cossy, J. Ritter Reaction: Recent Catalytic Developments. Eur. J. Org. Chem. 2012, 19-28.

(65) Kniep, F.; Rout, L.; Walter, S. M.; Bensch, H. K. V.; Jungbauer, S. H.; Herdtweck, E.; Huber, S. M. 5-Iodo-1,2,3triazolium-Based Multidentate Halogen-Bond Donors as Activating Reagents. Chem. Commun. 2012, 48, 9299-9301.

(66) Kniep, F.; Walter, S. M.; Herdtweck, E.; Huber, S. M. 4,4'Azobis(halopyridinium) Derivatives: Strong Multidentate Halogen-Bond Donors with a Redox-Active Core. Chem. Eur. J. 2012, 18, 1306-1310.

(67) For a review, see: Gao, X.; Liu, J.; Zuo, X.; Feng, X.; Gao, Y. Recent Advances in Synthesis of Benzothiazole Compounds Related to Green Chemistry. Molecules 2012, 25, 1675.

(68) Zirakzadeh, A.; Groß, M. A.; Wang, Y.; Mereiter, K.; Spindler, F.; Weissensteiner, W. Biferrocene-Based Diphosphine Ligands: Synthesis and Application of Walphos Analogues in Asymmetric Hydrogenations. Organometallics 2013, 32, 1075-1084.

(69) Urbano, A.; del Hoyo, A. M.; Martínez-Carrión, A.; Carreño, M. C. Asymmetric Synthesis and Chiroptical Properties of Enantiopure Helical Ferrocenes. Org. Lett. 2019, 21, 46234627.

(70) Mamane, V. The Diastereoselective ortho-Lithiation of Kagan's Ferrocenyl Acetal. Generation and Reactivity of Chiral 2-Substituted Ferrocenecarboxaldehydes. Tetrahedron: Asymmetry 2010, 21, 1019-1029.

(71) Riant, O.; Samuel, O.; Flessner, T.; Taudien, S.; Kagan, H. B. An Efficient Asymmetric Synthesis of 2-Substituted Ferrocenecarboxaldehydes. J. Org. Chem. 1997, 62, 67336745.

(72) Dhameja, M.; Pandey, J. Bestmann-Ohira Reagent: A Convenient and Promising Reagent in the Chemical World. Asian J. Org. Chem. 2018, 7, 1502-1523.

(73) Ferber, B.; Top, S.; Welter, R.; Jaouen, G. A New Efficient Route to Chiral 1,3-Disubstituted Ferrocenes: Application to the Syntheses of $(R \mathrm{p})-$ and $(S \mathrm{p})-17 \alpha-\left[\left(3^{\prime}-\right.\right.$ formylferrocenyl)ethynyl] estradiol. Chem. Eur. J. 2006, 12, 2081-2086.

(74) Jelsch, C.; Ejsmont, K.; Huder, L. The Enrichment Ratio of Atomic Contacts in Crystals, an Indicator Derived from the Hirshfeld Surface Analysis. IUCrJ 2014. 1, 119-128.

(75) Torubaev, Y. V.; Lyssenko, K. A.; Barzilovich, P. Y.; Saratov, G. A.; Shaikh, M. M.; Singh, A.; Mathur, P. Self-Assembly of Conducting Cocrystals via Iodine $\cdots \pi(\mathrm{Cp})$ Interactions. CrystEngComm 2017, 19, 5114-5121.

(76) Baldrighi, M.; Bartesaghi, D.; Cavallo, G.; Chierotti, M. R.; Gobetto, R.; Metrangolo, P.; Pilati, T.; Resnati, G.; Terraneo, G. Polymorphs and Co-Crystals of Haloprogin: An Antifungal Agent. CrystEngComm 2014, 16, 5897-5904. 
(77) AIMAll (Version 19.10.12), Todd A. Keith, TK Gristmill Software, Overland Park KS, USA, 2019 (aim.tkgristmill.com).

(78) Lu, T.; Chen, F. Multiwfn: A Multifunctional Wavefunction Analyzer. J. Comput. Chem. 2012, 33, 580-592.
(79) Lu, T.; Chen, F. Quantitative analysis of molecular surface based on improved Marching Tetrahedra algorithm. J. Mol. Graph. Model. 2012, 38, 314-323.

Table of Contents (TOC)

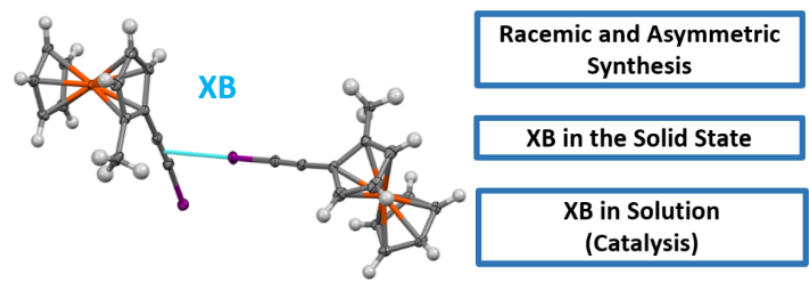

